\title{
Özel Güvenlik Sektöründe Çalışanların Örgütsel Politika Algıları ile İşten Ayrılma Niyetleri Arasındaki iliş̧kiye İş Doyumlarının Aracılık Etkisi ${ }^{1}$
}

\author{
Prof. Dr. Serap BENLIGiRAY² - Dr. Uğur DEMiRCi³
}

Başvuru Tarihi: 12.01 .2020

Kabul Tarihi: 14.10 .2020

Makale Türü: Araştırma Makalesi

\section{Öz}

Bu araştırmanın temel amacı özel güvenlik sektöründe çalışanların iş doyumlarının, örgütsel politika algıları ile işten ayrılma niyetleri arasındaki ilişkiye etkisini tespit etmektir. Araştırmanın evrenini Antalya'da çalışan özel güvenlik görevlileri oluşturmaktadır. Yapılan analize tesadüfi örneklem kullanılarak uygulanan anket sonrasında ulaşılan 996 gözlem birimi dahil edilmiştir. Araştırmada Ferris ve Kaçmar (1992) tarafindan geliştirilen Örgütsel Politika Algısı Ölçeği; Scott ve arkadaşları (1999) tarafından geliştirilen İșten Ayrılma Niyeti Ölçeği ile Weiss ve arkadaşları (1967) tarafından geliştirilen Minnesota İş Doyum Ölçeği kullanılmıştır. Araştırma sonuçlarına göre iş doyumunun örgütsel politika algısı ile işten ayrılma niyeti arasındaki ilişkide kısmi aracı etkiye sahip olduğu tespit edilmiştir.

Anahtar Kelimeler: Özel Güvenlik Sektörü, İş Doyumu, Örgütsel Politika Algısı, Isşten Ayrılma Niyeti

Atıf: Benligiray, S. ve Demirci, U. (2020). Özel güvenlik sektöründe çalışanların örgütsel politika algıları ile işten ayrılma niyetleri arasındaki ilişkiye iş doyumlarının aracılık etkisi. Anadolu Üniversitesi Sosyal Bilimler Dergisi, 20(4), 23-50.

\footnotetext{
${ }^{1} 2020$ yılı öncesi araştırma verileri kullanılmış olduğundan geriye dönük etik kurul izni gerekmemektedir.

${ }^{2}$ Anadolu Üniversitesi, İşletme, Yönetim Organizasyon Anabilim Dall, sbenligi@anadolu.edu.tr, ORCID: 0000-0003-1004-8318

${ }^{3}$ Emniyet Genel Müdürlügü, Özel Güvenlik Daire Başkanlığı, ugurdemirci@yahoo.com, ORCID: 0000-0002-4677-3477
} 


\title{
The Mediator Effect of Job Satisfaction on The Relationship between The Perceptions of Organizational Politics and Turnover Intent of The Employees in Private Security Sector
}

\author{
Prof. Dr. Serap BENLIGiRAY - Dr. Uğur DEMiRCi
}

\begin{abstract}
The main purpose of this study is to reveal the effect of private security officers' job satisfaction on the relationship between perception of organizational politics and turnover intention. The population of the study includes the private security officers working in Antalya. The data obtained from the questionnaire applied to 996 observation units determined by random sampling method were included in the analysis. In this study, Perception of Organizational Politics Scale developed by Ferris and Kacmar (1992), Intention to Quit Scale developed by Scott et al. (1999), and Job Satisfaction Scale developed by Weiss et al. (1967) were used. According to the result of the study, it was revealed that job satisfaction has partially mediator effect on the relationship between perception of organizational politics and turnover intention.
\end{abstract}

Keywords: Private Security Sector, Job Satisfaction, Perception Of Organizational Politics, Turnover Intention 


\section{Giriş}

Özel güvenlik, Emniyet Genel Müdürlüğü, Jandarma Genel Komutanlığı ve Sahil Güvenlik Komutanlığı gibi genel kolluk birimleri tarafından yapılan işler dışında, belirli bir alanda ve belirli yetkilerle çalışan, kamu güvenliğini tamamlayıcı ancak devletle herhangi bir organik bağı olmadan sunulan hizmetlerdir. Özel güvenlik birimleri "kişilere veya kurumlara ait özel alanlarda arama, el koyma, yakalama ve zor kullanma gibi kamu adına bazı yetkileri kullanma yetkisine sahip, mülkiyeti özel kurum ve kuruluşlara ait olan, ancak birimlerde çalışanların ve eğitilenlerin devletin denetimine tabi olduğu güvenlik hizmeti sunan birimlerdir" (Eryılmaz, 2006, s.124).

Dünyada güvenlik hizmeti verilecek alanların artması, zaman içinde genel kolluk birimlerinin görevlerini yerine getirmede yetersiz kalması, kaliteli özel güvenlik beklentisinin artması ve insanların güvenliklerini kendilerinin sağlamayı istemesi özel güvenlik hizmetlerinin doğmasına ve gelişmesine neden olmuştur (Engin, 2008, s.169-170). Özel güvenlik sektörü tüm dünyada olduğu gibi Türkiye'de de büyümeye devam etmektedir. Emniyet Genel Müdürlügü Özel Güvenlik Denetleme Başkanlığı verilerine göre, Türkiye'de 1435 güvenlik şirketi ile 444 özel güvenlik eğitim kurumu bulunmaktadır. Özel güvenlik sertifikası bulunan kişi sayısı 1 milyon 556 bin 250 iken 1 milyon 58 bin 626 özel güvenlik kimlik kartı sahibi şahıs bulunmaktadır. Aktif çalışan sayısı ise 283 bin 431'dir (İstanbul Güvenlik Anonim Şirketi [İSTGÜVEN], 2019).

Ülkemizde özel güvenlik işletmelerinin sektörün yapısıyla, mevzuatla, istihdamla, eğitimle, ücretlendirme ile ilgili pek çok sorunu bulunmaktadır. Sektörün önemli sorunlarından birisi de yüksek personel devir oranıdır (Türkiye Odalar ve Borsalar Birliği [TOBB], 2014). Yüksek personel devir oranı, yetkin personelin kaybedilmesi ve yerine yeni personelin yetiştirilmesi bağlamında sektörde bulunan işletmeler açısından zaman, para ve diğer kaynak kayıpları yaratarak yüksek maliyetlere neden olmaktadır. Bir işletmede belirli bir zaman periyodunda ne kadar çalışanın işten ayrıldığı ve ayrılanların yerine ne kadar yeni çalışan geldiği ile ilgili olan devir oranı, işten ayrılmanın çalışanın kendi isteğiyle gerçekleşmesi durumunda gönüllü devir oranı olarak adlandırılmaktadır. Gönüllü devir oranı, istenmeyen, zararlı ve mücadele edilmesi gereken en önemli insan kaynakları metriklerinden biridir.

Yetenekli çalışanları elde tutma üzerine yapılan birçok araştırma, çalışanların işletmelerden ayrılma kararlarının arkasındaki çeşitli nedenleri ve insanların bu tür seçimleri yapma süreçlerini anlamaya odaklanmıştır. İşletme yöneticileri bazı çalışanların neden işten ayrıldığını anlayarak, diğerlerinin neden kaldıkları hakkında daha iyi bir fikir edinebilir ve işten ayrılma kararlarını nasıl etkileyeceklerini öğrenebilirler.

Çalışanların işten ayrılmalarından önce işten ayrılma düşüncesi ortaya çıkmaktadır (Zeytinoglu, Denton, Davies, Baumann, Blythe, ve Boos, 2007, s.34). Yapılan araştırmalarda işten ayrılma niyeti ile gerçek işten ayrılma arasında pozitif ilişki olduğu tespit edilmiştir (Egan, Yang ve Bartlett, 2004; Mobley, 1982; Rizwan, Shahid, Shafiq, Tabassum, Bari ve Umer, 2013; Van Schalkwyk, Du Toit, Bothma, ve Rothmann,2010). Ancak, bu düşüncenin gerçek işten ayrılma davranışına dönüşmesinde birçok bireysel ve örgütsel faktör etkili olmaktadır (Hom, Caranikas-Walker, Prussia ve Griffeth, 1992). İșten ayrılma niyetini etkileyen faktörlerden birisi de örgütsel politika algısıdır. Örgütsel politika, "davranışların, kısa veya uzun vadeli kişisel çıkarları maksimize etmek için stratejik olarak tasarlandığı ve başkalarının çıkarları pahasına olan bir sosyal etki süreci” anlamına gelmektedir (Ferris, Russ ve Fandt, 1989). Siyasi davranışın kuruluşlar için yararlı veya zararlı olup olmadığı, bu davranışın gerçeklikten ziyade nasıl algılandığına bağlı olabilmektedir (Gandz ve Murray, 1980). Söz konusu algı gerçek olayların bir yanlıs yorumu olsa bile, algılayıcının bireysel olarak deneyimlenen olayları ve diğerlerinin davranışlarını yorumlamasına dayanmaktadır (Ferris, Frink, Bhawuk, Zhou ve Gilmore, 1996). Yapılan araştırmalar, oldukça politik bir ortamın yüksek stres, yüksek işten ayrılma niyeti, düşük çalışan memnuniyeti, zayıf bağlılık, zararlı örgütsel vatandaşlık davranışı ve düşük verimlilik gibi çalışma hayatı üzerindeki çeşitli olumsuz etkilerle ilişkili olduğunu iddia etmiştir. Bu nedenle örgütsel verimlilik ve karlılık zarar görmektedir (Chang, Rosen, Siemieniec ve Johnson, 2012; Ferris, Adams, Kolodinsky, Hochwarter ve Ammeter, 2002; Harris, Harris ve Harvey, 2007; Kacmar ve Baron, 1999).

Alan yazında örgütsel politika algısı ile işten ayrılma niyetini arasında ilişki olduğunu ortaya koyan çalışmalar mevcuttur (Ahmed, 2018; Başar ve Varoğlu, 2016; Gbadamosi ve Chinaka, 2011; Harris, James ve 
Boonthanom, 2005; Javed, Gulzar ve Hussain, 2015; Yusof, Zulkiffli, Padlee ve Yusof, 2018). Bununla birlikte bu araştırmalarda genel olarak iki değişken arasında anlamlı ve pozitif ilişki tespit edilmiştir. Ancak alan yazındaki araştırmalar her ne kadar örgütsel politika algısı ile iş tutumları arasındaki ilişkiyi ortaya koysalar da bunların arasındaki mekanizma henüz tam olarak ortaya konmuş değildir (Cho ve Yang, 2018, s.61; Huang, Chuang, ve Lin, 2003). Ayrıca araştırma sonuçları incelendiğinde örgütsel politika algısı ile işten ayrılma niyeti arasındaki ilişki düzeyinin farklılaştığı da görülmektedir. Bu sonuçların değişkenlik göstermesi iki değişken arasındaki ilişkiyi etkileyen bazı faktörlerin olabileceğini düşündürmektedir. Alan yazında bu düşünceyi doğrulayan bulgulara ve sonuçlara dair çalışmalar mevcuttur (Chang, Rosen ve Levy, 2009; Chhetri, Afshan, ve Chatterjee, 2016; Huang, Chuang ve Lin, 2003). İki değişken arasındaki ilişkiyi etkileyen faktörlerin bulunması ise, bu ilişkiyi etkileyen başka faktörlerin de bulunabileceğine işaret etmektedir (Baron ve Kenny, 1986).

İş doyumu hem örgütsel politika algısı (Ayobami ve Ofoegbu, 2013; Yusof ve diğerleri, 2018) hem işten ayrılma niyeti (Demirci, 2019a; Yücel ve Demirel, 2013; Yüksel ve Yüksel, 2014) ile ilişkilidir. Ayrıca alan yazında iş doyumunun birçok iş tutumu ilişkisinde aracı rolü oynadığ bilinmektedir (Crede ve diğerleri, 2007; Rahman ve diğerleri, 2014; Yousef, 2002). Bu nedenle iş doyumunun örgütsel politika ile işten ayrılma niyeti ilişkisini etkileyebileceğini değerlendirmek mümkündür. Ancak alan yazında bu hipotezi doğrulayan bir çalışmaya rastlanmamıştır. Araştırma "İ̧̧ doyumu, örgütsel politika algısı ile işten ayrılma niyeti arasında var olduğu bilinen ilişkiyi etkilemekte midir?" sorusuna cevap bulmak amacıyla gerçekleştirilmiştir. Araştırmanın genel amacı doğrultusunda nicel paradigma çerçevesinde gerçekleştirilen çalışma neticesinde, iş doyumunun örgütsel politika algısı ile işten ayrılma niyeti arasındaki ilişkide kısmi aracı etkisi bulunduğu tespit edilmiştir.

\section{Alan Yazın}

$\mathrm{Bu}$ bölümde araştırma kapsamında ele alınan örgütsel politika algısı, işten ayrılma niyeti ve iş doyumu incelenerek aralarındaki ilişki alanyazındaki örnekleriyle ortaya konacaktır.

\section{Örgütsel Politika Algısı}

Politik alanlar olarak örgütlerdeki (Mintzberg, 1983, 1985) politika konusu 1960’lı yıllarla birlikte örgütsel davranış alan yazınına girmeye başlamıştır. Ancak 1980’li yıllara kadar bu konu üzerine çok yoğun araştırmaların olmadığ 1 görülmektedir (Gandz ve Murray, 1980). Bu konuda önemli teorik öneriler 1980’li yıllarda ortaya konmakla birlikte, asıl çabaların artarak ivme kazanması Ferris, Russ ve Fandt (1989) ve Kacmar ve Ferris'in (1991) çalışmalarıyla açtıkları yoldan ilerlemiştir. Bu çalışmaların ortaya koyduğu modeller çerçevesinde görgül araştırmalar yapılmaya başlanmıştır. Söz konusu araştırmaların temel amacı, örgütsel politikanın alan yazında çoğunlukla vurgulanan olumsuz sonuçlarını anlamak ve örgütler açısından sorun yaratan bu tür uygulamaları tam olarak ortaya koymak olmuştur (Meisler ve Vigoda-Gadot, 2014).

Hayatın bir gerçeği olarak kabul edilen örgütlerdeki politika (Ferris ve Kacmar, 1992, s.93), örgütün yapısına, kültürüne ve büyüklüğüne göre çeşitli yoğunlukta hüküm sürebilmektedir (Witt, Andrews ve Kacmar, 2000). Örgütsel politika, örgütlerde belirsizliğin veya ihtilafın olduğu durumlarda bireylerin arzuladıkları hedeflere ulaşmak için gücü ve diğer kaynakları elde etmeye, geliştirmeye ve kullanmaya yönelik örgüt içindeki faaliyetleri içermektedir (Pfeffer, 1981, s.7). Güç ilişkileri olarak kısaca ifade edilebilen örgütsel politikanın tanımı üzerinde alan yazında tam olarak bir anlaşma bulunmamaktadır (Khan ve Hussein, 2016, s.570). Kacmar ve Baron (1999, s.4) örgütsel politikayı, diğer iş arkadaşlarının veya kendi örgütlerinin fayda ve çıkarına saygı duymadan bireylerin kendi menfaatlerini artırma hedefine yönelik eylemleri olarak tanımlamaktadır. Mayes ve Allen (1977, s.675) ise, örgütsel politikayı, örgüt tarafından onaylanmayan sonuçları elde etmek veya onaylanan sonuçlara örgüt tarafından onaylanmayan araçlarla/yöntemlerle ulaşmak amacıyla etkileme sürecinin yönetilmesi şeklinde ifade etmiştir. Örgütsel politika, örgüt içerisindeki grupların diğer grupları etkilemek ya da örgütsel amaçlar, kararlar, kaynak tahsisleri, ilke ve pratikleri veya örgüt dışındaki grupları etkilemek için kullandıkları informel taktik ve yaklaşımlardır (Zaleznik, 1999).

Örgütsel politika veya politik davranış resmi olarak izinli olmayan, onaylanmayan ve geniş çapta kabul görmeyen, bireyleri ve grupları resmi otoriteye karşı kışkırtan çatışmacı davranışlar ile aynı zamanda örgüt 
çalışanlarını kızdırmasına rağmen örgütün gelişimi için örgüte hizmet edebilecek davranışları içeren paradoksal bir kavramdır (Mintzberg, 1985, s.134-152). Bu nedenle politik davranışın yüksek işten ayrılma, yüksek iş kaygısı, düşük işe katılım, düşük iş doyumu (Ferris, Frink, Galang, Zhou, Kacmar ve Howard, 1996), düşük örgütsel vatandaşlık davranışı, düşük performans (Chang, Rosen ve Levy, 2009; Miller, Rutherford ve Kolodinsky, 2008), düşük örgütsel bağlllık, ihmalkarlık (Vigoda, 2001), düşük örgütsel güven (Aybar ve Marşap, 2018) düşük örgütsel adalet, tükenmişlik (Yüksel, 2013) ve örgütsel sinizm (Ferris ve diğerleri, 2002) gibi olumsuz sonuçları bulunmakla birlikte; verimlilik artışı, rekabet, pozisyon geliştirme, otorite genişlemesi gibi (Kumar ve Ghadially, 1989; Vigoda ve Drory, 2006) örgütler açısından olumlu sonuçları da bulunmaktadır. Örgütsel politikanın örgütler açısından olumsuz sonuçlarını önlemek ve bunu kontrol etmek için çeşitli örgütsel ve yönetsel unsurlar yararlı olabilmektedir. Örgütsel politika algısını kontrol etmekte kullanılabilecek faktörler arasında şeffaf ve adil örgüt çevresi, rol açıklığı, imkanların çokluğu ve kaynakların bolluğu sayllabilmektedir (Muhammad, 2007; Poon, 2003; Thau ve Mitchell, 2010; Valle ve Perrewe, 2000).

Politik davranışlar, uygulanış şekillerinden çok birey ve çalışanlar tarafından algılanış biçimlerine göre örgüt için yararlı veya zararlı sonuçlar doğurabilmektedir (Gandz ve Murray, 1980; Parker, Dipboye ve Jacson, 1995, s.892). Bu nedenle çalışanların örgütsel politika algılarını şekillendiren faktörlerin doğru analiz edilmesi gerekmektedir. Örgütsel politika algısını örgütsel, iş çevresi, kişisel ve demografik olmak üzere birçok faktör etkilemektedir. Örgütsel politika algısını etkileyen örgütsel faktörler merkezileşme, biçimselleşme, hiyerarşik seviye ve örgütsel büyüklük; iş çevresi faktörleri yükselme firsatları, kariyer geliştirme, geri besleme, hesap verebilirlik, kişi-örgüt uyumu, katılım, iş arkadaşları ve yöneticilerle iletişim; kişisel faktörler Makyavelizm, olumlu ve olumsuz duygu durumu; demografik faktörler ise yaş, cinsiyet, görev süresi ve etnik kökendir (Ferris ve diğerleri, 2002).

Örgütsel politika algısının alan yazında kabul gören genel politik davranış, ilerlemek için gerekeni yapmak, ücret ve terfi politikaları şeklinde üç boyutu bulunmaktadır. Genel politik davranış örgütlerdeki kuralların ve prosedürlerin net olmadığı, kararların genelde belirsizlik altında verildiği ve kaynakların görece kıt olduğu durumlarda ortaya çıkmaktadır (Kaçmar ve Carlson, 1997, s.629-630). İlerlemek için gerekeni yapma, kişisel çıkarlar doğrultusunda davranma ve bu çıkarlara yönelik algılanan tehditlere karşılık olarak misilleme yapma davranışı şeklinde karşımıza çıkmaktadır (Khan ve Hussain, 2016, s.571). Son boyut ise, örgütlerin performans değerlendirme sistemleri kapsamında ücret ve terfi politikalarının bulunması durumunda ortaya çıkmaktadır (Gull ve Zaidi, 2012, s.159). Bu durumda örgütler politik davranan çalışanları ödüllendirirken, diğer çalışanları istemeden de olsa politik davranmaları yönünde teşvik etmiş olmaktadırlar (Khan ve Hussain, 2016).

\section{İşten Ayrılma Niyeti}

Nitelikli çalışanların örgütlerde kalmalarının sağlanması yönetimlerinin önde gelen sorunları arasında yer almaktadır. Çünkü bunun aksi, örgütler için zaman ve para kaybıyla sonuçlanmaktadır. SHRM araştırması direkt yeniden işe alma ve yerleştirme giderlerinin bir çalışanın yıllık maaşının 50\% ila 60\%' 1 arasında olduğunu göstermiştir. Bu maliyetin içinde yeni çalışanın bulunması ve işe yerleştirilmesi, eğitilmesi, alıştırılması, boş geçen zaman, deneyimsiz personelin daha az verimli olması vb. pek çok unsur yer almaktadır (Allen, 2008). Yüksek devir oranı ayrıca işletmenin performansını etkilemekte ve yönetmesi gittikçe daha da zorlaşmaktadır. Genel olarak bir örgütteki çalışanların bir dönemdeki giriş çıkış hareketleri şeklinde ifade edilen iş gücü devri istenmeyen düzeylere eriştiğinde, örgütsel etkenlik (Price ve Mueller, 1986) ve verimlilik (Yılmaz ve Halıcı, 2010) olumsuz yönde etkilenmektedir. Bu kapsamda özellikle gönüllü devir oranı yüksekliği örgütler açısından istenmeyen bir durum olarak karşımıza çıkmaktadır. Bu nedenle örgütler personel devir oranlarının istenilen seviyede tutulması yönünde çaba göstermektedirler.

Yapılan araştırmalar gönüllü olarak işten ayrılmanın karmaşık bir süreç olduğunu göstermiştir. Bazı bireyler işten ani bir dürtüyle ayrılma kararı verseler de, çoğunun başlangıçta mevcut işlerini olası alternatiflere göre değerlendirmek, ne yapacağı hakkında niyetler geliştirmek ve çeşitli iş arama davranışlarına katılmak için zaman harcamak gibi davranışlar gösterdikleri tespit edilmiştir. Araştırmalar bazı işten ayrılmaların bireyin rolünden memnuniyeti ve örgüte bağll1ık gibi temel iş tutumlarını etkilediğini ortaya koymuştur. Düşük memnuniyet ve bağlılık vazgeçmeyi, başka işler araştırmayı, alternatif fırsatları karşılaştırmayı ve işten ayrılma niyetini içeren geri çekilme sürecini başlatabilmektedir. İşletme bu süreci etkili bir şekilde yönetemediği takdirde sonuç işten ayrılmayla neticelenebilmektedir. Bu durumdaki çalışanlar ayrıca, devamsızlık, gecikme 
ve düşük performans gibi çekilme göstergesi sayılabilecek başka herhangi bir iş davranışı da üretebilmektedir (Engin, 2008).

Alan yazında gerçekleştirilmiş çalışmalar işten ayrılma niyetinin gerçek işten ayrılma davranışının en büyük ve önemli belirleyicisi olduğunu ortaya koymaktadır (Egan ve diğerleri, 2004; Griffeth ve diğerleri, 2000; Lambert, Lynne Hogan ve Barton, 2001; Mobley, 1982; Rizwan ve diğerleri, 2013; Shore, Newton ve Thornton, 1990; Van Schalkwyk ve diğerleri, 2010). Bilinçli ve kasten örgütten ayrılma düşüncesi (Tett ve Meyer, 1993, s.262) olarak tanımlanabilecek olan işten ayrılma niyeti ise örgütsel, bireysel ve çevresel birçok faktörden etkilenme sonrasında birey tarafından işten ayrılma davranışına dönüşmektedir (Hom ve diğerleri, 1992, s.905). Örgüt bünyesinde verilen ödüller, alternatif işin kalitesi ve şartları, çalışanın işine yapmış olduğu yatırım, yöneticilerin davranışları, maaş ve ödüllendirme uygulamaları, çalışanın yaşı ve medeni durumu, genel işsizlik düzeyi ve alternatif yeni iş olanaklarının varlığı işten ayrılma niyetini etkileyen bu faktörler arasında sayllabilmektedir (Cotton ve Tuttle, 1986, s.62; Taslak, 2015).

İşten ayrılma niyeti birçok iş tutumundan da negatif veya pozitif yönde etkilenmektedir. Alan yazında liderlik (Alper-Ay ve Keleş, 2017; Taşlıyan ve Hırlak, 2016), örgütsel bağlllık (Cohen, 1998; Porter ve diğerleri, 1974; Terason, 2018), örgütsel destek (Zhang, 2018), mesleki bağllılk, örgütsel özdeşleşme (Çelik ve Yıldız, 2018), örgütsel güven (Akın ve diğerleri, 2018), örgütsel vatandaşlık davranışı (Paille, 2006), birey-örgüt uyumu (Uysal-Irak, 2014), tükenmişlik (Acker, 2008), öğrenme motivasyonu (Tolay-Sabuncuoğlu, 2007), sinizm (Demirci ve Tekiner, 2019; Yasım ve Uğur, 2016), iş aile iklimi (O'Neill ve diğerleri, 2009), iş aile çatı̧̧ması (Sidin ve diğerleri, 2016), örgütsel adalet (Ölçer, 2015), işe gömülmüşlük (Büyükbeşe ve Gökaslan, 2018), stres (Derik, 2019), pozitif psikolojik sermaye (Şevik, 2019), örgütsel sessizlik (Uslu ve Aktaş, 2017), örgütsel öğrenme (Emami ve diğerleri, 2012), işyeri zorbalığı (Serçeoğlu ve diğerleri, 2016), çatışma (Güzel ve Ayazlar, 2014), iş doyumu (Baltac1, 2018; Demirci, 2019a; Mosadeghrad, ve diğerleri, 2011) ve örgütsel politika (Başar ve Varoğlu, 2016; Harris ve diğerleri, 2005) işten ayrılma niyeti ile istatistiki olarak anlamlı olacak şekilde ilişkilendirilmiştir.

\section{Örgütsel Politika Algısı ve İşten Ayrılma Niyeti İlişkisi}

Alan yazında örgütsel politika algısı ile işten ayrılma niyeti ilişkisine dair yapılmış çalışma sonuçları bu iki değişken arasında anlamlı ve pozitif bir ilişki bulunduğunu işaret etmektedir (Yusof ve diğerleri, 2018; Ahmed, 2018; Başar ve Varoğlu, 2016; Chang ve diğerleri, 2009; Chhetri ve diğerleri, 2016; Gbadamosi ve Chinaka, 2011; Harris ve diğerleri, 2005; Javed ve diğerleri, 2015; Karatepe, 2011; Khalid ve Ishaq, 2015; Poon, 2004). Ancak araştırma sonuçları incelendiğinde bu iki değişken arasındaki ilişki düzeyinin farklılaştığı anlaşılmaktadır.

Yusof ve arkadaşları (2018) Malezya'da kamu denizcilik biriminde çalışanların katılımıyla yaptıkları araştırmada örgütsel politika algısı ile işten ayrılma niyeti arasındaki ilişkiyi .239 olarak tespit etmiştir. Başar ve Varoğlu (2016) Ankara'da bir kamu kurumunun merkez biriminde gerçekleştirdikleri araştırmada bu iki değişken arasındaki ilişkiyi .410 şeklinde saptamıştır. Gbadamosi ve Chinaka (2011) Nijerya'da üniversite çalışanları üzerinde gerçekleştirmiş oldukları araştırma neticesinde bu iki değişken arasındaki ilişkiyi .830 olarak hesaplamıştır. Bu araştırmalardan, Abbas ve arkadaşlarının (2015) Pakistan'da farklı örgütlerde gerçekleştirmiş oldukları araştırma sonuçları örgütsel politika algısı ile işten ayrılma niyeti arasındaki istatistiki ilişkinin pozitif ancak anlamlı olmadığını (insignificant) göstermiştir. Bu alan yazın incelemesine dayanılarak araştırmanın ilk hipotezi aşağıdaki şekilde oluşturulmuştur:

\section{$H_{1}$ : Örgütsel politika algısı ile işten ayrılma niyeti arasında anlamlı ve pozitif yönlü bir ilişki vardır.}

\section{İş Doyumu}

Bireysel ve örgütsel açıdan birçok önemi bulunan iş doyumu, örgüt başarısını belirleyen en önemli faktörler arasında yer alması sebebiyle örgütlerin temel amacı haline gelmiştir (Bernal, Gargallo, Marzo ve Rivera, 2005, s.279-280). İş doyumu çalışanların işlerini ve tecrübelerini değerlendirmeleri neticesinde ortaya çlkan duygusal bir durumdur (Locke, 1983). Muchinsky (2000) iş doyumunu, insanların işleriyle ilgili duygularını yansıttıkları bir tutum olarak tanımlamıştır. Genellikle olumlu bir tutum şeklinde değerlendirilen iş doyumu çalışanın işiyle ne kadar mutlu olduğunun göstergesi (Vieira, 2005, s.39), işini olumlu ve zevk veren bir uğraş olarak 
değerlendirmesinin bir sonucudur (Davis, 1988, s.96). Bunun tersi, yani işe karşı duyulan hoşnutsuzluk da iş doyumsuzluğunu ifade etmektedir (Özdemir, 2006, 70).

Çalışanların iş doyumlarını etkileyen bireysel ve örgütsel faktörler bulunmaktadır. İş doyumunu etkileyen bireysel özellikler cinsiyet, yaş, medeni durum, mesleki konum, eğitim düzeyi, kıdem, kişilik, hizmet süresi ve zeka; örgütsel özellikler ise işin niteliği, denetim biçimi, yönetim tarzı, iletişim, ücret, yükselme imkanları, rekabet, çalışma şartları, terfi ve ödüllendirme, yetki devri, hizmet içi eğitim şeklinde sayılabilir (Akınc1, 2002, s.6). İş doyumunu etkileyen iş tutumları da mevcuttur. Bunlar arasında iş-aile çatışması (Çelikkalp, Temel ve Bilgiç, 2019), stres (Kaymaz ve Erbi, 2018), rol çatışması, rol belirsizliği (Akar ve Yıldırım, 2008), algılanan amir desteği (Kurt, 2010), psikolojik sermaye (Ocak, Güler ve Basım, 2016), etik liderlik, örgütsel bağlllık (Çelik, Dedeoğlu, ve İnanır, 2015), örgütsel adalet, örgütsel güven (Alpkan, Dilek ve Bozlağan, 2005), örgütsel toksisite (Kasalak, 2019), motivasyon (Zeynel ve Çarıkçı, 2015), etik iklim (Naktiyok ve Yıldırım, 2018), örgütsel özdeşleşme (Başar ve Basım, 2015) ve örgütsel politika algısı (Wang, 2018; Hassan, Vina, ve Ithnin, 2017) sayılabilir.

İş doyumu örgütlerin etkenlik ve verimliklerine (Yılmaz, 2016; Bitmiş, Güney ve Demirel, 2014) doğrudan etki yapmakla birlikte, bu etkinlik ve verimliliğe katkı sağlayan birçok iş tutumunu da etkilediği bilinmektedir. Söz konusu tutumlardan yaşam doyumu (Maden Turgut, 2010), motivasyon (Orhaner ve Mutlu, 2019), örgütsel bağlllık (Çankaya, Gürdal, Tunç, ve Orhan, 2018), mesleki bağlllık (Demirci, 2019b), örgütsel vatandaşlık davranışı (Yeşilyurt ve Koçak, 2013), örgütsel adalet (Yıldırım, 2007), örgütsel güven (Semercioğlu, Tengilimoğlu ve Semercioğlu, 2012) ve mesleki adanmışlık (Tan ve Ulaş, 2016) ile iş doyumu arasında pozitif bir ilişki bulunduğuna dair araştırmalar bulunmaktadır. Bununla birlikte tükenmişlik (Çivici, 2016), sanal kaytarma (Çavuşoğlu ve Palamutçuoğlu, 2017), duygusal tükenme (Alanoğlu, 2019), devamsızlık (Brief, 1998; Özkalp ve Kırel, 2013) ve işten ayrilma niyeti (Demirci, 2019a; Masum, Azad, Hoque, Beh, Wanke ve Arslan, 2016) gibi örgütler açısından olumsuz sonuçlar doğurabilecek tutumlar üzerinde de iş doyumunun negatif etkisi olduğu tespit edilmiştir. Tüm bunlara ek olarak alan yazında yapılan inceleme sonucunda iş doyumunun birçok iş tutumu arasındaki ilişkide aracı (Crede ve diğerleri, 2007; Rahman ve diğerleri, 2014; Töngel, 2015; Yousef, 2002) ve düzenleyici (Betz, 1971; Pekmezci ve diğerleri, 2017; Ridaryanto, 2017) olarak görev yaptığ da görülmektedir.

\section{Örgütsel Politika Algısı ve iş Doyumu iliş̧kisi}

İş doyumu örgütsel politika algısının en çok çalışılan çıktıları arasındadır (Kaçmar ve Baron, 1999). Alan yazında örgütsel politika algısı ile iş doyumu arasındaki ilişkiye dair yapılmış araştırma sonuçları bu iki değişken arasında orta düzeyde anlamlı ve negatif yönlü bir ilişki bulunduğunu göstermektedir (Ayobami ve Ofoegbu, 2013; Chen ve diğerleri, 2017; Eryılmaz ve İspirli, 2014; Ferris, Frink, Galang ve diğerleri, 1996; Ojiabo ve Alagah, 2017; Valle ve Witt, 2001; Yusof ve diğerleri, 2018). Ojiabo ve Alagah (2017) Amerika'da sağlık sektörü üzerinde gerçekleştirdikleri araştırma neticesinde örgütsel politika algısı ve iş doyumu arasındaki ilişkiyi -.646 olarak tespit etmiştir. Chen ve arkadaşları (2017) Tayvan'da sağlık sektörü üzerinde gerçekleştirdikleri araştırma neticesinde bu iki değişken arasındaki ilişkiyi -.600 olarak tespit etmişlerdir. Eryılmaz ve İspirli (2014) Anakara, İstanbul ve İzmir'deki kamu kurumlarında çalışanların katılımıyla yaptıkları araştırma neticesinde bu iki değişken arasındaki ilişkiyi -.474 şeklinde tespit etmişlerdir. Valle ve Witt (2001)'ın Amerika'da müşteri hizmetleri görevlileri üzerine yaptıkları araştırmanın sonuçları örgütsel politika algısı ile iş doyumu arasındaki ilişkinin -.410 olduğunu ortaya koymuştur. Bu alan yazın incelemesine dayanılarak araştırmanın ikinci hipotezi aşağıdaki şekilde oluşturulmuştur:

\section{$\mathrm{H}_{2}$ : Örgütsel politika algısı ile iş doyumu arasında anlamlı ve negatif yönlü ilişki vardır.}

\section{İş Doyumu ve İşten Ayrılma Niyeti îlişkisi}

Alan yazında iş doyumu ile işten ayrılma niyeti ilişkisine dair gerçekleştirilmiş araştırmalar incelendiğinde bu iki değişken arasında negatif yönlü anlamlı bir ilişki bulunduğu anlaşılmaktadır (Demirci, 2019a; Cote ve Morgan, 2002; Frenkel, Sanders ve Bednall, 2013; Masum ve diğerleri, 2016; Yücel ve Demirel, 2013; Yüksel ve Yüksel, 2014). Ancak bu iki değişken arasındaki ilişki düzeyi çalışmalara göre farklılık göstermektedir. Örneğin, Frenkel ve arkadaşları (2012) Avusturalya'da finans, sağlık, iletişim ve yiyecek-içecek sektöründe çalışanlar üzerinde gerçekleştirdikleri çalışma neticesinde iş doyumu ile işten ayrılma niyeti arasındaki ilişki 
düzeyini -.680 şeklinde tespit etmişken; söz konusu ilişki düzeyi Demirci'nin (2019a) İstanbul'da çalışan özel güvenlik görevlileri üzerinde gerçekleştirdiği çalışmada -.583; Yücel ve Demirel'in (2013) elektronik sektöründe çalışanlar üzerinde yaptıkları çalışmada ise -.378 olarak hesaplanmıştır. Bu alan yazın incelemesine dayanılarak araştırmanın üçüncü hipotezi aşağıdaki şekilde oluşturulmuştur:

\section{$H_{3:}$ İş doyumu ile işten ayrılma niyeti arasında anlamlı ve negatif yönlü ilişki vardır.}

\section{Örgütsel Politika Algısı ile İşten Ayrııma Niyeti ilişskisine İş Doyumunun Aracılık Etkisi}

Alan yazında örgütsel politika ile işten ayrılma niyeti arasındaki ilişkiye dair yapılmış araştırmaların sonuçlarında bu iki değişken arasındaki ilişki düzeyi tutarlılık göstermemektedir (Abbas ve diğerleri, 2015; Başar ve Varoğlu, 2016; Gbadamosi ve Chinaka, 2011; Yusof ve diğerleri, 2018). Bu durum iki değişken arasındaki ilişkiyi etkileyen bazı faktörlerin bulunabileceğini düşündürmektedir. Alan yazın incelendiğinde lider-üye etkileşimi (Chhetri ve diğerleri, 2016), iş stresi ve sosyal değişim (Chang ve diğerleri, 2009), işe bağlanma (Javed ve diğerleri, 2015; Karatepe, 2011), duygusal bağlllık (Ayhan ve Gürbüz, 2013) ve tükenmişlik (Huang ve diğerleri, 2003) gibi bazı iş tutumlarının örgütsel politika ile işten ayrılma niyeti arasındaki ilişkide aracılık rolü oynadıkları anlaşılmaktadır. İki değişken arasındaki ilişkiyi etkileyen bir başka unsurun bulunması, bu ilişkiyi etkileyen başka unsurların da bulunabileceğini işaret etmektedir (Baron ve Kenny, 1986). İşten ayrılma niyeti ile ilişkili olduğu bilinen iş doyumu (Demirci, 2019a; Cote ve Morgan, 2002; Frenkel ve diğerleri, 2012; Masum ve diğerleri, 2016; Yücel ve Demirel, 2013; Yüksel ve Yüksel, 2014) örgütsel politika algisından etkilenmektedir (Ayobami ve Ofoegbu, 2013; Chen ve diğerleri, 2017; Eryılmaz ve İspirli, 2014; Ferris, Frink, Galang ve diğerleri, 1996; Ojiabo ve Alagah, 2017; Valle ve Witt, 2001 Yusof ve diğerleri, 2018). Ayrıca alan yazında birçok iş tutumunun öncülü veya sonucu olarak karşımıza çıkan iş doyumunun çoğu iş tutumları arasındaki ilişkide aracılık rolü üstlendiği de bilinmektedir (Crede ve diğerleri, 2007; Rahman ve diğerleri, 2014; Yousef, 2002). Tüm bu nedenlerle iş doyumunun, örgütsel politika algısı ile işten ayrılma niyeti arasında var olduğu bilinen ilişkiyi etkileyebileceği düşünülmektedir. Alan yazın incelemesinde bu hipotezin doğrulanmasına ilişkin bir araştırmaya rastlanmamıştır. Bu alan yazın incelemesi neticesinde araştırmanın dördüncü hipotezi aşağıdaki şekilde oluşturulmuştur:

\section{$H_{4}:$ İş doyumu, örgütsel politika algısı ile işten ayrılma niyeti arasındaki ilişkiyi etkilemektedir.}

\section{Yöntem}

$\mathrm{Bu}$ bölümde araştırmanın amacı ve modeli ile veri toplama araçlarına ilişkin bilgi verildikten sonra araştırmanın evren ve örneklemine değinilerek veri analizinde kullanılacak teknikler ifade edilecektir.

\section{Araştırmanın Amacı ve Modeli}

$\mathrm{Bu}$ araştırmanın amacı örgütsel politika algısı ile işten ayrılma niyeti ilişkisinde iş doyumunun aracılık etkisinin olup olmadığını test etmektir. Nicel paradigma çerçevesinde gerçekleştirilmiş olan çalışmanın deseni ilişkisel araştırma şeklinde belirlenmiştir. Bu amaçla Antalya'da çalışan özel güvenlik görevlilerine, kendilerinin örgütsel politika, işten ayrılma niyeti ve iş doyumlarını belirlemek üzere ilgili ölçekleri içeren anket uygulanmıştır.

İki değişken arasındaki ilişkiyi etkileyen üçüncü bir değişkenin etkisinin doğru analiz edilebilmesi için araştırma modelinin doğru oluşturulması gerekmektedir. Genellikle bağımlı ve bağımsız değişken arasındaki ilişkiyi etkileyen üçüncü değişkenin rolüne ilişkin tahminlerde problemler yaşanmaktadır. Bu problemlerin daha araştırma başında çözülmesi ve doğru araştırma modelinin oluşturulması, araştırma sonuçlarının sağlığ açısından önem taşımaktadır. Bu bağlamda örgütsel politika algısı ile işten ayrılma niyeti arasındaki ilişkide rolü olabileceği değerlendirilen iş doyumunun hangi tür etkiye sahip olduğunu tespit etmek amaciyla Baron ve Kenny'nin (1986) araştırmasındaki hususlar göz önüne alınmıştır.

Baron ve Kenny (1986) araştırmasında düzenleyici ve aracı değişkenlerin araştırmalarda sıklıkla birbirleriyle karıştırıldığını ifade ederek aralarındaki belirgin farkları şu şekilde sıralamıştır: Düzenleyici değişken açısından en büyük varsayım, bu değişkenin bağımlı ve bağımsız değişkenlerle korelasyonunun bulunmasının 
istenmemesidir. Bir diğer varsayım ise düzenleyici değişken ile bağımsız değişkenin aynı düzeyde bulunması, yani aralarında ardıl-öncül ilişskinin bulunmamasıdır. Bu varsayım düzenleyici ile aracı değişken arasındaki en büyük fark olarak ortaya çıkmaktadır. Aracı değişkene ilişkin ortaya konacak modelde ise öncelikle bağımsız değişken bağımlı değişkenin sebebi olmakla birlikte bağımsız değişkenin aynı zamanda aracı değişkenin de sebebi olması gerekmektedir. Ayrıca bağımlı değişkenin aracı değişkenin sebebi olması da istenmeyen bir durumdur (Baron ve Kenny, 1986; Burmacioğlu, Polat ve Meydan, 2013). Bu açıklamalar ışığında iş doyumunun hem bağımlı değişken hem de bağımsız değişkenle ilişkili olması; bununla birlikte bağımsız değişken olan örgütsel politika algısının iş doyumu üzerinde etkisi olduğunun bilinmesi sebebiyle iş doyumunun bu iki değişken arasında aracı değişken olarak etkili olabileceğini değerlendirmek mümkün olabilmektedir. Tüm bu nedenler ve gerçekleştirilen alan yazın incelemesi neticesinde araştırma kapsamında aşağıdaki model oluşturulmuştur.

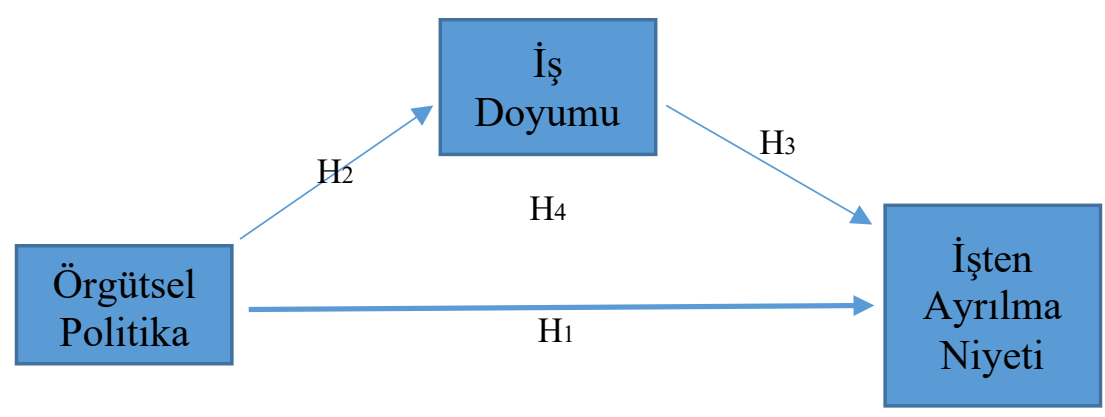

Şekil 1. Araştırmanın Modeli

\section{Veri Toplama Aracı}

Araştırmada veri toplama aracı olarak anket formundan yararlanılmıştır. Ankette, Ferris ve Kaçmar (1992) tarafından geliştirilen Örgütsel Politika Algısı Ölçeği; Scott, Connaughton, Diaz-Saenz, Maguire, Ramirez, Richardson, Shaw ve Morgan (1999) tarafından geliştirilen İşten Ayrılma Niyeti Ölçeği ve Weiss, Dawis, England ve Lofquist (1967) tarafından geliştirilen Minnesota İş Doyum Ölçeği kullanılmıştır. Anket demografik bilgilere ilişkin 7, Örgütsel Politika Algısı Ölçeğine ilişkin 31, İşten Ayrılma Niyeti Ölçeğine ilişkin 4 ve İş Doyumu Ölçeğine ilişkin 20 olmak üzere toplam 62 ifadeden oluşmaktadır.

Örgütsel Politika Algısı Ölçeği 3 boyut (Üstün -politik- davranışı, çalışma arkadaşlarının davranışı, örgüt politikaları ve uygulamaları) ve 31 ifadeden oluşmaktadır. Ölçek Türkçe’ye uyarlanarak geçerliliği ve güvenilirliği gerçekleştirildikten sonra birçok araştırmada kullanılmıştır (Akbaş, 2016; Aybar ve Marşap, 2018; Kurnaz, 2019; Mohan Bursalı ve Bağc1, 2011). Orijinal ölçeğin güvenirlik katsayısı .910’dur.

İşten Ayrılma Niyeti Ölçeği (Scott ve diğerleri, 1999) tek faktörlüdür ve 4 ifadeye sahiptir. Ölçek daha önceden Türkçeye çevrilerek geçerlilik ve güvenirlik testleri yapıldıktan sonra çeşitli araştırmalarda kullanılmıştır (Aylan, 2012; Demirci, 2019a; Erbaşı, 2019). Orijinal ölçeğin güvenirlik katsayıs1 .830’dur.

Minnesota İş Doyum Ölçeğinin (Weiss ve diğerleri, 1967) biri 100, diğgeri 20 soruluk iki versiyonu mevcuttur. Araştırmada kısa versiyon kullanılmıştır. Oran (1989) tarafından Türkçeye çevrilen ölçek, geçerlilik, güvenirlik testleri yapıldıktan sonra birçok araştırmada kullanılmıştır (Dağdeviren, Musaoğlu, Ömürlü ve Öztora, 2011; Demirci, 2019a; Köroğlu, 2012; Sevimli ve İşcan, 2005; Hançer, 2003). Orijinal ölçeğin güvenirlik katsayısı .830 'dur.

\section{Evren ve Örneklem}

Bu araştırmanın evrenini Antalya'da çalışan özel güvenlik görevlileri oluşturmaktadır. Antalya'da Ekim 2018 itibariyle 8778 özel güvenlik görevlisi çalışmaktadır. Bunların 3945’i kamuda, 4833’ü ise özel sektörde istihdam edilmektedir. Antalya ekonomisi turizm, tarım ve ticaret sektörleri üzerine yoğunlaşmıştır (Antalya Büyükşsehir Belediyesi, 2006, s.26). Antalya'daki özel güvenlik görevlilerinin 1546’sı da (\% 17,6) turizm sektörüne bağlı işletmelerde çalışmaktadır. 
Araştırmada tesadüfi örneklem kullanılmıştır. Online olarak hazırlanmış olan anket Antalya'da bulunan tüm kamu ve özel sektör özel güvenlik birim yöneticileri ile özel güvenlik şirket yöneticilerine Ekim 2018 başında gönderilmiştir. Yöneticiler vasıtasıyla tüm özel güvenlik görevlilerine ulaşılmaya çalışılarak evrene yansız ulaşmak amaçlanmıştır. Cevaplar günlük olarak kontrol edilmiştir. Araştırmaya katılım devam etmediğinde anket Ekim 2018 sonunda katılımcılara kapatılmıştır. Araştırma kapsamında analize uygun 996 gözlem birimi elde edilmiştir. Bu örneklem büyüklüğünün evreni yansıtacak nitelikte olduğu değerlendirilmiştir (Yazıcıoğlu ve Erdoğan, 2004, s.50).

\section{Veri Analizinde Kullanılan Teknikler}

Araştırma modeli çerçevesinde aracı değişkenin bağımsız değişken ve bağımlı değişken arasındaki ilişkiye etkisini belirlemek amacıyla Baron ve Kenny (1986) tarafından belirlenen analiz yöntemi kullanılmıştır. Baron ve Kenny’e (1986) göre bir değişkenin aracı etkiye sahip olduğunun ortaya konabilmesi için üç koşulun sağlanması gerekmektedir;

- Bağımsız değişkenin aracı değişken üzerinde bir etkisinin bulunması gerekmektedir.

- Bağımsız değişkenin bağımlı değişken üzerinde bir etkiye sahip olması gerekmektedir.

- Aracı değişkenin bağımlı değişken üzerinde bir etkiye sahip olması ve aracı değişken analize dahil edildiğinde bağımsız değişken ile bağımlı değişken arasındaki ilişki düzeyi azalmalı (kısmi aracı etki) veya tamamiyla ortadan kalkmalıdır (tam aracı etki).

Aracı etkinin belirlenmesi amacıyla korelasyon ve regresyon analizleri gerçekleştirilmiştir. Bununla birlikte özel güvenlik görevlilerinin örgütsel politika algıları, iş doyumları ve işten ayrılma niyetleri düzeylerini belirlemek üzere ortalama ve standart sapma gibi istatistikler kullanılmıştır.

\section{Bulgular}

Araştırmaya katılanlara iliş̧in demografik bilgiler Tablo 1'de yer almaktadır. Tablo 1 incelendiğinde araştırmaya katılanların büyük bir bölümünün $(\% 78,1)$ erkek olduğu; büyük bir bölümünün $(\% 77,3) 30$ yaş ve üzerinde bulunduğu; büyük çoğunluğunun $(\% 66,4)$ lise mezunu olduğu ve özel sektörde istihdam edildiği (\%73,6 oranında) görülmektedir. Katılımcıların yüzde 41,5’i altı yıl ve üzeri kıdeme sahipken, \%58,5'inin kıdemi beş yıldan azdır ve yine çoğu $(\% 62,2)$ asgari ücret almaktadır.

Tablo 1

Araştırmaya Katılanların Demografik Özellikleri

\begin{tabular}{llcc}
\hline & \multicolumn{1}{c}{ Gruplar } & Frekans $(\mathbf{n})$ & Yüzde (\%) \\
\hline Cinsiyet & Erkek & 778 & 78,1 \\
Yaş & Kadın & 218 & 21,9 \\
& $18-23$ yaş arası & 43 & 4,3 \\
& $24-29$ yaş arası & 183 & 18,4 \\
& $30-35$ yaş arası & 334 & 33,5 \\
Eğitim düzeyi & 36 yaş ve üzeri & 436 & 43,8 \\
& İlköğretim & 135 & 13,6 \\
& Lise & 661 & 66,4 \\
& Ön lisans & 112 & 11,2 \\
& Lisans & 83 & 8,3 \\
İstihdam şekli & Lisans üstü & 5 & 0,5 \\
& Kamu & 263 & 26,4 \\
Çalışma süresi & Özel sektör & 733 & 73,6 \\
& 1 yıl ve altı & 321 & 32,2 \\
& $2-5$ yıl arası & 262 & 26,3 \\
& 6-10 yıl arası & 271 & 27,2 \\
Ücret & 11 yıl ve üzeri & 142 & 14,3 \\
& $1500-2000$ arası & 620 & 62,2 \\
& 2001-2500 arası & 259 & 26,0 \\
& 2501-3000 arası & 74 & 7,4 \\
Örgütteki pozisyonu & Yönetici & 43 & 4,3 \\
& Yönetilen & 107 & 10,7 \\
\hline
\end{tabular}


Araştırmaya katılanların ilgili ölçeklere vermiş oldukları cevapların ortalamaları Tablo 2'de yer almaktadır. Tablo 2 incelendiğinde, katılımcıların örgütsel politika algıları ortalamasının 2,77 (orta), iş doyumu düzeylerinin 3,49 (yüksek) ve işten ayrılma niyeti düzeylerinin 2,59 (düşük) olduğu anlaşılmaktadır. Standart sapmalar da bu örneklemin heterojen bir grup olduğunu ve ölçeklerin ayırt edici özelliğinin yüksek olduğunu göstermektedir.

Tablo 2

Örgütsel Politika Algısı, İş Doyumu ve İşten Ayrılma Niyeti Puan Ortalamaları

\begin{tabular}{lccccc}
\hline & $\mathbf{N}$ & Ort. & Ss & Min. & Max. \\
\cline { 2 - 6 } Örgütsel politika algısı & 996 & 2,77 &, 494 & 2,11 & 3,53 \\
İş doyumu & 996 & 3,49 &, 721 & 1,00 & 5,00 \\
İşten ayrılma niyeti & 966 & 2,59 &, 982 & 2,33 & 2,91 \\
\hline
\end{tabular}

Katılımcıların ilgili ölçeklere vermiş oldukları cevaplar bağlamında gerçekleştirilen güvenilirlik analizi neticesinde, örgütsel politika algısı ölçeğinin Cronbach Alpha değeri ,851, iş doyumu ölçeğinin Cronbach Alpha değeri ,948 ve işten ayrılma niyeti ölçeğinin Cronbach Alpha değeri ,820 olarak hesaplanmıştır (Bkz. Tablo 3). Ayrıca normallik testi sonucu ölçek maddelerine ilişkin skewness ve kurtosis değerleri $+1,5$ ve $-1,5$ arasında gerçekleşmiştir. Bu sonuçlara göre verilerin normal dağılım gösterdiği değerlendirilmiştir (Tabachnick and Fidell, 2013).

Tablo 3

Korelasyon ve Güvenilirlik Analizi Sonuçları

\begin{tabular}{|c|c|c|c|}
\hline Değişkenler & $\begin{array}{c}\text { Örgütsel politika } \\
\text { algısı }\end{array}$ & İş doyumu & $\begin{array}{c}\text { İşten ayrılma } \\
\text { niyeti }\end{array}$ \\
\hline 1.Örgütsel politika algısı & $(, 851)$ & & \\
\hline $\mathrm{r}$ & 1,000 & & \\
\hline $\mathrm{p}$ & ,000 & & \\
\hline 2.İş doyumu & & $(, 948)$ & \\
\hline $\mathrm{r}$ &,$- 507^{* *}$ & 1,000 & \\
\hline $\mathrm{p}$ & ,000 & ,000 & \\
\hline 3.İșten ayrılma niyeti & & & $(, 820)$ \\
\hline $\mathrm{r}$ &, $446^{* *}$ &,$- 579^{* *}$ & 1,000 \\
\hline $\mathrm{p}$ & ,000 & 000 & 000 \\
\hline
\end{tabular}

Tablo 4

Katılımcıların Cinsiyetleri, Örgütteki Pozisyonları ve İstihdam Şekilleri ile İstihdam Ayrılma Niyetleri Arasındaki Fark

\begin{tabular}{llccccc}
\hline \multirow{1}{*}{ İŞTEN AYRILMA NİYETI } & & $\mathbf{N}$ & $\mathbf{X}$ & $\mathbf{S s}$ & $\mathbf{t}$ & $\mathbf{p}$ \\
\cline { 2 - 7 } Cinsiyet & Erkek & 778 & 2,66 & 1,008 & 4,415 &, $000^{*}$ \\
\multirow{2}{*}{ Örgütteki pozisyonu } & Kadın & 218 & 2,36 &, 845 & & \\
& Yönetici & 107 & 2,66 &, 907 &, 778 &, 438 \\
\multirow{2}{*}{ İstihdam şekli } & Yönetilen & 889 & 2,58 &, 991 & & \\
& Kamu & 263 & 2,40 & 1,005 & $-3,559$ &, $000^{*}$ \\
& Özel & 733 & 2,66 &, 966 & & \\
\hline
\end{tabular}

$\mathrm{p}<.05$

İşten ayrılma niyetine ilişkin fark analizleri yapılmıştır. Katılımcıların cinsiyet, örgütteki pozisyon ve istihdam şekilleri ile işten ayrılma niyetleri arasında gerçekleştirilen $t$ Testi sonuçları Tablo 4'te yer almaktadır. Tablo 4 incelendiğinde, $\mathrm{t}$ Testi sonuçlarına göre $\% 95$ güven aralığında gerçekleştirilen analiz neticesinde cinsiyet ve istihdam şekli değişkenlerinin significant değerinin $(\mathrm{p}<.05)$ anlamlı olduğu, örgütteki poziyon değişkeninin sinificant değerinin anlamsız olduğu anlaşılmaktadır. Bu sonuçlara göre erkek özel güvenlik görevlilerinin kadınlara göre ve özel sektörde istihdam edilen özel güvenlik görevlilerinin kamuda istihdam edilenlere göre 
işten ayrılma niyetlerinin yüksek olduğu; yönetici ve yönetilenlerin işten ayrılma niyeti düzeylerinde herhangi bir farklılı̆̆ın bulunmadığı ifade edilebilir.

Katılımcıların yaş, eğitim düzeyi, çalışma süresi ve ücretleri ile işten ayrılma niyetleri aeasında gerçekleştirilen ANOVA Testi sonuçları Tablo 5’ten incelenebilir.

Tablo 5

Katılımcıların Yaşları, Eğitim Düzeyleri, Çalışma Süreleri ve Kazandıkları Ücret ile İşten Ayrılma Niyetleri Arasındaki Fark (ANOVA Testi)

\begin{tabular}{|c|c|c|c|c|c|c|c|}
\hline \multirow{18}{*}{ 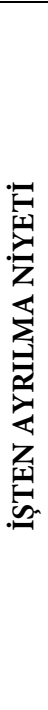 } & & & $\mathbf{N}$ & $\mathbf{X}$ & Ss & $\mathbf{F}$ & $\bar{p}$ \\
\hline & \multirow[t]{4}{*}{ Yaş } & $18-23$ aras 1 & 43 & 2,91 & 1,185 & \multirow[t]{4}{*}{3,198} & \multirow[t]{4}{*}{, $023^{\star}$} \\
\hline & & 24-29 aras1 & 183 & 2,55 & 941 & & \\
\hline & & $30-35$ aras1 & 334 & 2,67 & 1,001 & & \\
\hline & & 36 yaş ve üzeri & 436 & 2,52 & ,955 & & \\
\hline & \multirow[t]{5}{*}{ Eğitim düzeyi } & İlköğretim & 135 & 2,55 & ,958 & \multirow[t]{5}{*}{6,199} & \multirow[t]{5}{*}{$.000^{*}$} \\
\hline & & Lise & 661 & 2,51 & 968 & & \\
\hline & & Ön lisans & 112 & 2,88 & ,925 & & \\
\hline & & Lisans & 83 & 2,90 & 1,088 & & \\
\hline & & Lisansüstü & 5 & 3,05 & 908 & & \\
\hline & \multirow[t]{4}{*}{ Çalışma süresi } & 1 yil ve altı & 321 & 2,65 & ,961 & \multirow[t]{4}{*}{2,486} & \multirow[t]{4}{*}{,059 } \\
\hline & & $2-5$ yıl arası & 262 & 2,65 & ,970 & & \\
\hline & & $6-10$ yil arası & 271 & 2,56 & 1,00 & & \\
\hline & & 11 yıl ve üzeri & 142 & 2,40 & ,995 & & \\
\hline & \multirow[t]{4}{*}{ Ücret } & $1500-2000$ aras 1 & 620 & 2,73 & ,962 & \multirow[t]{4}{*}{12,862} & \multirow[t]{4}{*}{, $000^{*}$} \\
\hline & & $2001-2500$ aras1 & 259 & 2,42 & ,990 & & \\
\hline & & $2501-3000$ aras 1 & 74 & 2,20 & ,947 & & \\
\hline & & 3001 ve üzeri & 43 & 2,23 & 874 & & \\
\hline
\end{tabular}

Tablo 5 incelendiğinde yaş, eğitim düzeyi ve ücret değişkenlerine göre katılımcıların işten ayrılma niyetlerinin anlamlı bir şekilde farklılaştığı $(\mathrm{p}<.05)$ anlaşılmaktadır. Bunun üzerine yaş, eğitim düzeyi ve ücret değişkenlerine ilişkin ayrı ayrı TUKEY Testi gerçekleştirilmiştir. Yaş değişkenine ilişkin gerçekleştirilen TUKEY Testi sonucunda hiçbir grubun istatistiki olarak anlamlı şekilde farklılaşmadığı $(\mathrm{p}<.05)$ tespit edilmiştir (Bkz. Tablo 6).

Tablo 6

Katılımcıların Yaşları ile İşten Ayrılma Niyetleri Arasındaki Fark (TUKEY Testi)

\begin{tabular}{llcc}
\hline \multirow{2}{*}{$\mathbf{1 8 - 2 3}$ arası } & Değişkenler & Ortalamalar arası fark & $\mathbf{p}$ \\
\cline { 2 - 4 } & $24-29$ arası &, 36 &, 133 \\
$\mathbf{2 4 - 2 9}$ arası & $30-35$ arası &, 24 &, 417 \\
& 36 yaş ve üzeri &, 40 &, 055 \\
& $18-23$ arası &,- 36 &, 133 \\
$\mathbf{3 0 - 3 5}$ arası & $30-35$ arası & -12 &, 572 \\
& 36 yaş ve üzeri &, 03 &, 973 \\
$\mathbf{3 6}$ yaş ve üzeri & $18-23$ arası &,- 24 &, 417 \\
& $24-29$ arası &, 12 &, 572 \\
& 36 yaş ve üzeri &, 15 &, 138 \\
\hline $\mathbf{p}<.05$ & $18-23$ arası &,- 40 &, 055 \\
& $24-29$ arası &,- 04 &, 973 \\
& $30-35$ arası &,- 15 &, 138 \\
\hline
\end{tabular}

Araştırmaya katılanların işten ayrılma niyetlerinin eğitim değişkenine göre farklılık gösterip göstermediğinin anlaşılması için gerçekleştirilen ve Tablo 7'de yer alan TUKEY Testi sonuçları incelendiğinde; lise mezunlarının işten ayrılma niyeti düzeyleri ile ön lisans ve lisans mezunları arasında istatistiksel olarak anlamlı 
farklılaşmanın meydana geldiği, diğer gruplar arasında herhangi bir anlamlı farklılı̆̆ın olmadığı $(\mathrm{p}<.05)$ görülmüştür. Bu sonuçlara göre ön lisans ve lisans mezunu özel güvenlik görevlilerinin lise mezunu olanlardan daha yüksek işten ayrılma niyetine sahip oldukları ifade edilebilir.

Tablo 7

Katılımcıların Eğitim Düzeyleri ile İşten Ayrılma Niyetleri Arasındaki Fark (TUKEY Testi)

\begin{tabular}{|c|c|c|c|}
\hline & Değişkenler & Ortalamalar arası fark & $\mathbf{p}$ \\
\hline \multirow[t]{4}{*}{ İlköğretim } & Lise & ,05 & ,981 \\
\hline & Ön lisans &,- 33 &, 061 \\
\hline & Lisans &,- 35 &, 079 \\
\hline & Lisansüstü &,- 50 &, 796 \\
\hline \multirow[t]{4}{*}{ Lise } & İlköğretim &,- 05 & ,987 \\
\hline & Ön lisans &,- 38 &, $001^{*}$ \\
\hline & Lisans &,- 39 &, $005^{*}$ \\
\hline & Lisansüstü &,- 54 &, 726 \\
\hline \multirow[t]{4}{*}{ Ön lisans } & İlköğretim &, 33 &, 061 \\
\hline & Lise &, 38 &, $001^{*}$ \\
\hline & Lisans &,- 02 & 1,000 \\
\hline & Lisansüstü &,- 17 & ,996 \\
\hline \multirow[t]{4}{*}{ Lisans } & İlköğretim & ,35 & ,079 \\
\hline & Lise &, 39 &, $005^{\star}$ \\
\hline & Ön lisans &, 01 & 1,000 \\
\hline & Lisansüstü &,- 14 & ,997 \\
\hline \multirow[t]{4}{*}{ Lisansüstü } & İlköğretim &, 50 &, 796 \\
\hline & Lise &, 54 &, 726 \\
\hline & Ön lisans &, 17 & ,996 \\
\hline & Lisans &, 15 & ,997 \\
\hline
\end{tabular}

Katılımcıların işten ayrılma niyetlerinin aldıkları ücrete göre farklılık gösterip göstermediğine ilişkin yapılan TUKEY Testi sonuçları Tablo 8'de yer almaktadır. Tablo 8 incelendiğinde 1500-2000 TL arası ücret alan özel güvenlik görevlileri ile diğer tüm gruplar arasında istatistiksel olarak anlamlı bir farklılaşmanın meydana geldiği, diğer gruplar arasında ise herhangi bir anlamlı farklılığın bulunmadığı $(\mathrm{P}<.05)$ anlaşılmaktadır. Bu sonuçlara göre 1500-2000 TL arası ücret alan özel güvenlik görevlilerinin diğer gruplara göre daha fazla işten ayrılma niyetine sahip oldukları söylenebilir.

Tablo 8

Katılımcıların Kazandıkları Ücret ile İşten Ayrılma Niyetleri Arasındaki Fark (TUKEY Testi)

\begin{tabular}{|c|c|c|c|}
\hline \multirow{3}{*}{$1500-2000$ aras 1} & Değişkenler & Ortalamalar arası fark & $\mathrm{p}$ \\
\hline & $2001-2500$ arasi & ,30 &, $000^{*}$ \\
\hline & 2501-3000 aras1 &, 53 &, $000^{\star}$ \\
\hline \multirow{4}{*}{ 2001-2500 aras 1} & 3001 ve üzeri &, 50 &, $005^{\star}$ \\
\hline & $1500-2000$ aras 1 &,- 30 &, $000^{*}$ \\
\hline & 2501-3000 arasi & ,23 & 270 \\
\hline & 3001 ve üzeri & ,20 &, 579 \\
\hline \multirow[t]{2}{*}{ 2501-3000 aras1 } & $1500-2000$ aras 1 &,- 53 &, $000^{*}$ \\
\hline & 2001-2500 arası &,- 23 & 270 \\
\hline & 3001 ve üzeri &,- 03 & ,999 \\
\hline \multirow[t]{3}{*}{3001 ve üzeri } & $1500-2000$ aras 1 &,- 50 &, $005^{\star}$ \\
\hline & 2001-2500 arasi &,- 20 &, 579 \\
\hline & $2501-3000$ arası & ,03 & ,999 \\
\hline
\end{tabular}


Ölçekler kapsamında gerçekleştirilen korelasyon analizi neticesinde örgütsel politika algısı ile iş doyumu arasında ve iş doyumu ile işten ayrılma niyeti arasında negatif yönlü ve anlamlı bir ilişki tespit edilmişken; örgütsel politika algısı ile işten ayrılma niyeti arasında pozitif yönlü ve anlamlı bir ilişki olduğu tespit edilmiştir (Bkz. Tablo 3). Bu sonuçlara göre $\mathrm{H} 1, \mathrm{H} 2$ ve $\mathrm{H} 3$ hipotezleri kabul edilmiştir.

Örgütsel politika algısı ile işten ayrılma niyeti arasındaki ilişkide iş doyumunun etkisinin olup olmadığını tespit etmek amacıyla hiyerarşik regresyon analizi yapılmıştır. Baron ve Kenny'nin (1986) çalışmasında belirtmiş olduğu gibi, öncelikle örgütsel politika algısı ile iş doyumu arasında bir regresyon analizi gerçekleştirilmiştir. Sonrasında örgütsel politika algısı ile işten ayrılma niyeti arasında bir regresyon analizi gerçekleştirilmiştir. Son olarak bu ikinci adıma iş doyumu da eklenerek analiz tekrarlanmıştır. Bu üç modele ilişkin regresyon analizi sonuçları Tablo 9'da sunulmuştur.

Tablo 9'da da görüleceği üzere örgütsel politika algısı ile iş doyumu arasında anlamlı bir ilişki olduğu tespit edilmiştir ve regresyon modeli istatistiksel olarak anlamlıdır $(\beta=-, 507$ ve $p<, 05)$. Böylelikle ilk koşul gerçekleşmiş olmaktadır. İkinci adımda gerçekleştirilen analiz neticesinde de örgütsel politika algısı ile işten ayrılma niyeti arasında anlamlı bir ilişki olduğu tespit edilmiştir ve regresyon modeli istatistiksel olarak anlamlıdır ( $\beta=, 446$ ve $\mathrm{p}<.05)$. Böylelikle ikinci koşul da gerçekleşmiş olmaktadır. Son olarak üçüncü adımda gerçekleştirilen regresyon analizi sonucu incelendiğinde ilişki düzeyinin halen istatistiksel olarak anlamlı olduğu $(\beta=, 205$ ve $p<.05)$ ancak beta sayısının ,507'den ,205'e gerilemiş olduğu anlaşılmaktadır. Bu sonuçlara göre örgütsel politika algısı ile işten ayrılma niyeti arasındaki ilişkide iş doyumunun kısmi aracı etkisinin olabileceğini ifade etmek mümkündür.

Tablo 9

Bağımsız Değişken Örgütsel Politika Algısı, Aracı Değişken İş Doyumu ve Bağımlı Değişken İşsten Ayrılma Niyeti Arasında Gerçekleştirilen Regresyon Analizi Sonuçları

\begin{tabular}{|c|c|c|c|c|c|c|c|c|c|}
\hline \multicolumn{2}{|l|}{ Adımlar } & B & $\mathbf{R}$ & $\mathbf{R}^{2}$ & $t$ & $\begin{array}{c}\text { Düzeltilmiş } \\
\mathbf{R}^{2} \\
\end{array}$ & $\begin{array}{c}\mathbf{R}^{2} \\
\text { değişisimi } \\
\end{array}$ & $p$ & $\begin{array}{c}\text { ANOVA F } \\
\text { değeri }\end{array}$ \\
\hline \multicolumn{2}{|c|}{$\begin{array}{l}\text { 1.Adım } \\
\text { Örgütsel politika algısı-İş } \\
\text { doyumu }\end{array}$} & ,507 & ,507 & ,257 & $-18,523$ & ,256 & ,257 & ,000 & 343,111 \\
\hline \multicolumn{2}{|c|}{$\begin{array}{l}\text { 2.Adım } \\
\text { Örgütsel politika algısı- } \\
\text { İşten ayrılma niyeti }\end{array}$} & ,446 & , 446 & 199 & 15,698 & , 198 & ,199 &, 000 & 246,431 \\
\hline $\begin{array}{l}\text { 3.Adım } \\
\text { Örgütsel } \\
\text { politika }\end{array}$ & $\begin{array}{l}\text { Örgütsel } \\
\text { politika } \\
\text { algisı }\end{array}$ & ,205 & & & 6,993 & & & & \\
\hline $\begin{array}{l}\text { algısı+İş } \\
\text { doyumu- } \\
\text { İşten } \\
\text { ayrılma } \\
\text { niyeti }\end{array}$ & İş doyumu & ,476 & ,606 & ,367 & $-16,239$ & ,366 & ,367 &, 000 & 287,634 \\
\hline
\end{tabular}

Gerçek aracı etkinin hesaplanabilmesi için Sobel Testi gerçekleştirilmiştir. Sobel Testi sonucunda 10,9470 olarak tespit edilen $\mathrm{Z}$ değeri anlamlıdır ( $\mathrm{p}<, 027)$ (Bkz. Tablo 10). Bu sonuçlara göre beta değerindeki azalmanın anlamlı olduğu ve iş doyumunun örgütsel politika algısı ile işten ayrılma niyeti arasındaki ilişkide kısmi aracılık yaptığı görünmektedir. Bu sonuçlara göre $\mathrm{H} 4$ hipotezi kabul edilmiştir.

Tablo 10

Sobel Testi Sonuçları

\begin{tabular}{lcccc}
\hline & Değerler & Test istatistikleri & Standart sapma & $\boldsymbol{p}$ \\
\hline $\boldsymbol{a}$ &, 112 & & & \\
$\boldsymbol{b}$ &, 126 & 2,2101 &, 00638 &, 027 \\
$\boldsymbol{S a}$ &, 040 & & & \\
$\boldsymbol{S} \boldsymbol{b}$ &, 035 & & &
\end{tabular}




\section{Tartışma ve Sonuç}

Örgütsel politika algısı ile işten ayrılma niyeti arasındaki ilişkiye, bu her iki değişkenle de ilişkisi olduğu bilinen iş doyumunun etkili olabileceği ön görülerek araştırma gerçekleştirilmiştir. Araştırma sonuçları bu hipotezi doğrulamıştır. İş doyumu bu iki değişken arasındaki ilişkide kısmi aracı etkiye sahiptir. Örgütsel politika algısı çalışanlarda yarattığı olumsuz tutum neticesinde işten ayrılma niyeti ile sonuçlanabilmektedir. Ancak bu araştırma sonuçları iş doyumu yüksek olan özel güvenlik görevlilerinin algıladıkları örgütsel politikanın daha az oranda işten ayrılma niyetine dönüşebileceğini ortaya koymaktadır. Bu nedenle çalışanlarının işten ayrılma niyetlerini kontrol etmek ve istenen düzeyde tutmak isteyen özel güvenlik örgütleri öncelikle örgütlerindeki politik iklimin negatif algılanmasını önleyecek tedbirler almalıdır. Bilindiği üzere politik davranışlar birey ve çalışanlar tarafından algılanış biçimine göre örgüt için yararlı veya zararlı sonuçlar doğurmaktadır (Gandz ve Murray, 1980; Parker ve diğerleri, 1995). Örgütsel politika algısının olumsuz sonuçlarından korunmak amacıyla şeffaf ve adil bir örgüt çevresi yaratılmalı, rol açıklığı sağlanmalı ve kaynaklara erişim kolaylaştırılmalıdır. Bununla birlikte özel güvenlik örgütleri çalışanlarının iş doyumlarını sağlayacak şekilde tedbirler almalıdir.

Yapılan analizler sonucunda ayrıca örgütsel politika algısı ile işten ayrılma niyeti arasında orta düzeyde pozitif bir ilişki tespit edilmiştir. Bu sonuçlar Başar ve Varoğlu’nun (2016) gerçekleştirmiş olduğu araştırma sonuçlarıyla uyuşmakla birlikte Yusof ve arkadaşlarının (2018) ve Gbadamosi ve Chinaka'nın (2011) gerçekleştirdikleri araştırma sonuçlarıyla uyuşmamaktadır. Bu araştırmada olduğu gibi diğer araştırmalarda da ilişkiyi etkileyen başka faktörlerin bulunma ihtimali sonuçların farklılaşmasındaki etken olabilir. Alan yazın incelendiğinde örgütsel politika algısının çıktıları arasında sayılan tükenmişlik, örgütsel adalet (Yüksel, 2013), örgütsel sinizm (Ferris ve diğerleri, 2002), örgütsel güven (Ayber ve Marsap, 2018), örgütsel bağlllık (Vigoda, 2001) ve örgütsel vatandaşlık davranışının (Chang ve diğerleri, 2009) işten ayrılma niyetiyle de ilişkili oldukları (Acker, 2008; Akın ve diğerleri, 2008; Demirci ve Tekiner, 2019; Terasan, 2019; Ölçer, 2015; Paille, 2006; Porter ve diğerleri, 2018; Yasim ve Uğur, 2016) görülmektedir. Bu nedenle, yukarıda sayılan bu tutumların örgütsel politika algısı ile işten ayrılma niyeti ilişkisinde etkili olabilecekleri değerlendirilebilir. Bundan sonraki çalışmalarda araştırmacılar bu iki değişken arasındaki ilişkiyi etkileyen faktörlerin olabileceğini göz önüne alarak araştırmalarını şekillendirmelidirler.

Araştırma sonuçlarında örgütsel politika algısı ile iş doyumu arasında ise orta düzeyde negatif bir ilişki tespit edilmiştir. Bu sonuçlar alan yazındaki diğer çalışma sonuçlarıyla uyuşmaktadır (Ayobami ve Ofoegbu, 2013; Chen ve diğerleri, 2017; Eryılmaz ve İspirli, 2014; Ferris ve diğerleri, 1996; Ojiabo ve Alagah, 2017; Valle ve Witt, 2001; Yusof ve diğerleri, 2018). Bununla birlikte araştırma sonuçlarında iş doyumu ile işten ayrılma niyeti arasında da orta düzeyde anlamlı negatif bir ilişki tespit edilmiştir. Bu sonuç Demirci'nin (2019a) gerçekleştirmiş olduğu araştırma sonucuyla uyuşmakla birlikte alan yazında farklı ilişki düzeylerinin tespit edildiğine dair araştırmalar da mevcuttur (Frenkel ve diğerleri, 2012; Yücel ve Demirel, 2013). Bu sonuçların iş doyumu ile işten ayrılma niyeti arasındaki ilişkiyi etkileyebilecek başka faktörlerin varlığını işaret ettiğini söylemek mümkündür. Alan yazın incelendiğinde iş doyumunun çıktıları arasında sayılan iş-aile çatışması (Çelikkalp ve diğerleri, 2019), psikolojik sermaye (Ocak ve diğerleri, 2016), liderlik, örgütsel bağlllık (Çelik ve diğerleri, 2015), örgütsel adalet, örgütsel güven (Alpkan ve diğerleri, 2005), motivasyon (Zeynel ve Çarıkçı, 2015) ve örgütsel özdeşleşmenin (Başar ve Basım, 2015) işten ayrılma niyetini de etkiledikleri (Akın ve diğerleri, 2018; Alper-Ay ve Keleş, 2017;Çelik ve Yıldız, 2018; Cohen, 1998; Ölçer, 2015; Sidin ve diğerleri, 2016; Şevik, 2019; Tolay ve Sabuncuoğlu, 2007) görülmektedir. Bundan sonraki çalışmalarda araştırmacıların bu unsurları da göz önüne almalarında fayda bulunduğu değerlendirilmektedir.

Araştırmada özel güvenlik görevlilerinin işten ayrılma niyetlerinin aldıkları ücrete göre farklılaştığı tespit edilmiştir. 1500-2000 TL arası ücret alan özel güvenlik görevlilerinin işten ayrılma niyeti düzeyleri diğerlerine göre daha yüksektir. Alan yazında ücret ile işsten ayrılma niyeti arasında ilişki olduğunu ortaya koyan araştırmalar mevcuttur (Demirci ve Ergen, 2020; Ghiselli ve diğerleri, 2001; Summers ve Henfrix, 1991). Demirci ve Ergen (2020) İstanbul'da gerçekleştirmiş oldukları araştırmada ücretin özel güvenlik görevlilerinin işten ayrılma niyetleri üzerinde önemli bir belirleyici olduğunu, özel güvenlik görevlilerinin aldıkları ücret arttıkça işten ayrılma niyetlerinin azaldığını ifade etmektedirler. Özel güvenlik mesleğinin ağır iş şartları göz önüne alındığında, asgari ücret alan görevlilerin aynı ücretle daha iyi şartlarda başka bir iş bulma imkanlarının 
bulunması durumunda, kolayca iş değişikliğine gidebilecekleri görülmektedir. Bu bağlamda özel güvenlik sektöründe yer alan örgütlerin işgören devir oranlarını istedikleri seviyede tutabilmeleri için ücret hususunu mutlaka göz önüne almaları gerektiği değerlendirilmektedir.

Araştırmada özel güvenlik görevlilerinin işten ayrılma niyetlerinin istihdam şekillerine göre farklılaştığı, özel sektörde çalışanların işten ayrılma niyeti düzeylerinin kamuda istihdam edilenlere göre daha yüksek olduğu görülmüştür. Alan yazında istihdam yerlerinin çalışanların işten ayrılma niyetleri üzerinde etkili olduğunu ortaya koyan çalışmalar mevcuttur (Demirci, 2019a; Demirci ve Tekiner, 2019; Çelik ve Yıldız, 2018; Wang ve diğerleri, 2012). Bu çalışmanın sonuçları Demirci (2019a), Demirci ve Tekiner (2019) ve Wang ve arkadaşlarının (2012) yapmış oldukları araştırma sonuçlarıyla örtüşmektedir. İşten ayrılma niyeti çevresel, işe ilişkin ve bireysel birçok faktörden etkilenebilmektedir (Cotton ve Tuttle, 1986). Bu bağlamda, kamuda çalışanların iş garantisi sebebiyle hissettikleri geleceğe yönelik güven duygusu böyle bir sonuca neden olmuş olabilir. Bununla birlikte bu sonuçlar bağlamında özel sektörde faaliyet gösteren örgüt yöneticilerine, özel güvenlik görevlilerinin işten ayrılma niyetlerini etkileyebilecek ödüllendirme ve yönetim tarzı gibi hususları doğru analiz ederek gerekli tedbirleri almaları önerilebilir.

Araştırmada eğitim seviyesi yükseldikçe özel güvenlik görevlilerinin işten ayrılma niyetlerinin yükseldiği tespit edilmiştir. Alan yazında bu sonucu destekleyen çalışma (Wang ve diğerleri, 2018) bulunmakla birlikte çalışanların işten ayrılma niyetlerinin eğitim seviyelerine göre farklılaşmadığını ortaya koyan çalışmalar da bulunmaktadır (Kurt, 2019; Öztürk Çiftçi ve diğerleri, 2015; Yıldız ve diğerleri, 2009). Ancak çalışanların eğitim seviyelerinin yükseldikçe, alternatif iş olanaklarının artması sebebiyle, bağllıklarının azaldığg bilinmektedir (Tanova ve Holtom, 2008). Bu nedenle, elde edilen bu sonuçların özel güvenlik sektörü açısından önemli olduğunu göz önüne alarak, personel devir oranı yüksek özel güvenlik örgütlerinin insan kaynakları politikalarını bu bağlamda belirlemeleri gerekir.

Araştırmada katılımcıların işten ayrılma niyetlerinin cinsiyetlerine göre farklılık gösterdiği, erkek özel güvenlik görevlilerinin kadınlara göre daha yüksek işten ayrılma niyetine sahip olduğu tespit edilmiştir. Alan yazında bu sonuçları destekleyen araştırmalar (Cotton ve Tuttle, 1986) bulunmakla birlikte, kadınların işten ayrılma niyetlerinin erkeklerden daha yüksek olduğunu (Yavuz ve Akça, 2018) ya da çalışanların işten ayrılma niyetlerinin cinsiyetlerine göre farklılaşmadığını ortaya koyan (Kurt, 2019; Yüksel ve Yüksel, 2014) araştırmaların da bulunduğu bilinmektedir. İşten ayrılma niyetini etkileyen birçok faktör bulunduğu (Cotton ve Tuttle, 1986) göz önüne alınarak cinsiyet değişkeninin diğer faktörlerle ele alınarak sonuçların değerlendirilmesinde fayda olduğu değerlendirilmektedir.

Araştırma sonuçlarının, iş doyumunun örgütsel politika algısı ile işten ayrılma niyeti arasındaki ilişkide oynadığı rolü ortaya koyması sebebiyle alan yazına önemli bir katkı sağlayacağı düşünülmektedir. Bununla birlikte bu iki değişken arasındaki ilişkiyi etkileyen diğer faktörlerin de ortaya çıkarılması yönünde çalışmalar yapılmasının gerekliliği göz ardı edilmemelidir. Ayrıca iş doyumu ile işten ayrılma niyeti arasındaki ilişkiyi etkileyen muhtemel unsurların tespiti de önem taşımaktadır. Bu yönde gerçekleştirilecek araştırmalara da ihtiyaç bulunduğu değerlendirilmektedir. Öte yandan yüksek personel devir oranı Türkiye'de özel güvenlik sektörü için önemli görülmektedir. Bu nedenle özel güvenlik görevlilerinin işten ayrılma niyetlerini etkileyen faktörlerin ortaya konulması yönünde gerçekleştirilecek araştırmalara ihtiyaç bulunduğu da düşünülmektedir. $\mathrm{Bu}$ araştırmanın da diğer araştırmalar gibi kısıtları bulunmaktadır. Öncelikle bu araştırma ilişkisel desende gerçekleştirilmiştir. Deneysel desende gerçekleştirilmiş bir çalışmanın sonuçlarının daha genellenebilir olacağ 1 düşünülmektedir. Ayrıca işten ayrılma niyeti ve örgütsel politika algısı birçok bireysel ve örgütsel faktörden etkilenebilmektedir. Bu araștırmanın örneklemini Antalya'da çalışan özel güvenlik görevlileri olușturmuştur. Bu nedenle ulaşlan sonuçlar sadece Antalya ili için genellenebilir niteliktedir.

Antalya, Türkiye'nin en önemli turizm bölgelerinden birisidir. Yüzde 17,6'sının turizm işletmelerinde istihdam edildiği göz önüne alındığında özel güvenlik görevlilerinin turizm sektörünün karşı karşıya kaldığg sorunlardan etkilenme olasıllğ̆ yüksektir. Ancak güvenlik unsurunun sürekliliği gereği, turizm işletmelerinde çalışan özel güvenlik görevlileri mevsimlik değil, diğer özel güvenlik görevlileri gibi sürekli istihdam edilmektedirler. Antalya'da yapılan araştırmalar turizm sektöründe çalışanların iş güvencesi algılarının işten ayrılma niyetlerini negatif yönde etkilediğini ortaya koymuştur (Alkaya, 2015; Dıgın ve Ünsar, 2010; 
Karacaoğlu, 2015; Tuncer, 2014; Yıldırım ve Yirik, 2014). Bu bağlamda Antalya özel güvenlik sektörünü diğer illerden çalışma ve iş koşulları açısından özellikle ayrıştıran bir yönünün bulunmadığı ifade edilebilir.

\section{Kaynakça}

Abbas, H.W., Shafique, M., Qadeer, F., Din, N.M.U., Ahmad, R. ve Saleem, S.S. (2015). Impact of perceptions of organizational politics on employees' job outcomes: The moderating role of self-efficacy and personal political skills. Sci.Int.(Lahore), 27(3), 2729-2734. Erişim adresi: https://papers.ssrn.com/sol3/sample_issues/ 1480989_CMBO.html

Acker, G.M. (2008). An examination of the relationships between workers and agencies characteristics and three outcome variables: Burnout, role stress, and intent to quit. American Journal of Psychiatric Rehabilitation, 11, 295-309. doi: 10.1080/15487760802186311

Ahmed, I. (2018). Organizational politics and turnover intention: A study from private colleges of Pakistan. International Journal of Business and Management Review, 6(4), 14-28. doi: 10.13140/RG.2.2.28303.02729

Akar, C. ve Yıldırım, Y.T. (2008). Yöneticilerin örgütsel bağlılık, iş tatmini ve rol stres kaynakları arasındaki ilişkiler: Yapısal denklem modeliyle beyaz et sektöründe bir alan uygulaması. Gazi Üniversitesi İktisadi ve İdari Bilimler Fakültesi Dergisi, 10(2), 97-113. Erişim adresi: https://dergipark.org.tr/tr/pub/gaziuiibfd/issue/28328/301040

Akbaş, A. (2016). Öğretmenlerin örgütsel politika algıları ile duygusal emek düzeyleri arasındaki ilişki (Yayınlanmamış yüksek lisans tezi). Uşak Üniversitesi Sosyal Bilimler Enstitüsü.

Akın, A., Şaylıkaya, M., Işık, M. ve Oktay, M. (2018, Haziran). Örgütsel güven ve örgütsel bağlllığın işten ayrılma niyeti üzerindeki etkisi üzerine bir araştırma. 3.Uluslararası Mesleki ve Teknik Bilimler Kongresinde sunulan bildiri, Gaziantep. Erişim adresi: http://www.igdir.edu.tr/duyuru/\%C4\%B1\%C4\%B1\%C4\%B1uluslararas\%C4\%B1-mesleki-ve-teknik-bilimler-kongresi-\%C3\%B6zet-kitab\%C4\%B1-duyurusu

Akıncı, Z. (2002). Turizm sektöründe işgören iş tatminini etkileyen faktörler: Beş yıldızlı konaklama işletmelerinde bir uygulama. Akdeniz İ̈BF Dergisi, 4, 1-25. Erişim adresi: https://kutuphane.dogus.edu.tr/mvt/pdf.php

Alanoğlu, M. (2019). Algılanan okul müdürü yönetim tarzları ile öğretmenlerin karara katılma, örgütsel adalet, iş doyumu ve tükenmişlik algıları arasındaki ilişkinin analizi (Yayınlanmamış doktora tezi). Fırat Üniversitesi Eğitim Bilimleri Enstitüsü.

Alkaya, S. (2015). İş güvencesi memnuniyeti ve çeşitli değişkenlerin işten ayrlma niyetine etkilerinin lojistik regresyon analizi ile incelenmesi. (Yayınlanmamış doktora tezi). Akdeniz Üniversitesi Sosyal Bilimler Ensrtitüsü.

Allen, D. G. (2008). Retaining talent a guide to analyzing and managing employee turnover. SHRM foundation's effective practice guidelines serie. Erişim adresi: https://www.shrm.org/hr-today/trendsand-forecasting/special-reports-and-expert-views/Documents/Retaining-Talent.pdf

Alper-Ay, F. ve Keleş, K. (2017). Etkileşimci ve dönüşümcü liderlik tarzlarının işten ayrılma niyeti ve iş performansı üzerinde etkisi. Gümüşhane Üniversitesi Sağllk Bilimleri Dergisi, 6(4), 193-203. Erişim adresi: https://dergipark.org.tr/tr/pub/gumussagbil/ issue/32215/ 369332

Alpkan, L., Dilek, H. ve Bozlağan, R. (2005). Liderlik tarzlarının güven ve adalet algısı yoluyla örgütsel bağll1ık, iş tatmini ve örgütsel vatandaşlık davranışı üzerinde etkileri. Milli Savunma Üniversitesi Savunma Bilimleri Dergisi, 4(1), 44-69. Erişim adresi: https://dergipark.org.tr/tr/pub/khosbd/issue/19238/204414 
Antalya Büyükşehir Belediyesi (2006). 2007-2011 Stratejik plan. Erişim adresi: http://www.sp.gov.tr/upload/xSPStratejikPlan/files/tCQMq+AntalyaBuyuksehirSP20072011.pdf

Aybar, S. ve Marşap A. (2018). Örgütsel politika algısı ile örgütsel bağlllık ilişkisinde örgütsel güvenin düzenleyici rolünün belirlenmesine yönelik İstanbul'daki üniveristelerde bir araştırma. İşletme Araştırmaları Dergisi, 10(2), 758-782. doi: 10.20491/isarder.2018.454

Ayhan, Ö. ve Gürbüz, S. (2013, Haziran). Algılanan örgütsel politikanın çalışanların işten ayrılma niyetine etkisinde duygusal bağlliğın rolü: kamu ve özel sektör çalışanların üzerinde bir araştırma. 21.Yönetim Organizasyon Kongresinde sunulan bildiri, Sakarya. Erişim adresi: $\mathrm{ftp} / / / \mathrm{ftp}$. sakarya.edu.tr/KUTUPHANE/yonetimkongresi.pdf

Aylan, S. (2012). Organizasyonlarda psikolojik şiddet (mobbing) ve işten ayrılma niyeti arasındaki ilişkiyi tespit etmeye yönelik konaklama işletmelerinde bir uygulama (Yayınlanmamış yüksek lisans tezi). Gazi Üniversitesi Eğitim Bilimleri Enstitüsü. Ankara.

Ayobami, A.P. ve Ofoegbu, O.E. (2013). Influence of perception of organizational politics on job satisfaction among university workers in Oyo Town, Nigeria. European Journal of Business and Management, 5(2), 162-169. Erişim adresi: https://iiste.org/Journals/index.php/EJBM/article/view/3939/3997

Baltacı, A. (2018). Din görevlilerinin iş doyumu, iş stresi, tükenmişlik ve işten ayrılma niyeti arasındaki ilişkiler: Çok önemli bir çalışma. Cumhuriyet İlahiyat Dergisi, 22, 1509-1536. doi: 10.18505/cuid.458233

Bannister, B. D., ve Griffith, R. W. (1986) Applying a causal analytic framework to the mobley, horner and hollingsworth turnover model: A useful reexamination. Journal of Management, 12(3), 433-443. doi: $10.1177 / 014920638601200312$

Baron, R.M. ve Kenny, D.A. (1986). The moderator-mediator variable distinction in social psychological research: Conceptual, strategic, and statistical considerations. Journal of Personality and Social Psychology, 51(6), 1173-1182. doi: 10.1037//0022-3514.51.6.1173

Başar, U. ve Basım, N. (2015). Effects of organizational identification on job satisfaction: Moderating role of organizational politics. Yönetim ve Ekonomi, 22(2), 663-683. Erişim adresi: https://dergipark.org.tr/tr/download/article-file/146221

Başar, U. ve Varoğlu, A.K. (2016). Örgütsel politika algısının ihmalkarlık üzerindeki etkisinde işten ayrılma niyetinin aracı rolü. Yönetim ve Ekonomi, 23(3), 751-765. doi: 10.18657/yonveek.281961

Bernal, J. G., Gargallo, C. A., Marzo, N. M. ve Rivera, T. P. (2005). Job satisfaction: Emprical evidence of gender differences. Women in Management Review, 20(4), 279-288. doi: 10.1108/09649420510599098

Betz, E.L. (1971). An investigation on job satisfaction as a moderator variable in predicting job success. Journal of Vocational Behavior, 1(2), 123-128. doi: 10.1016/0001-8791(71)90013-3

Bitmiş, M.G., Güney, S. ve Demirel, H. (2014). İletişim doyumu verimlilik ilişkisinde örgütsel bağllık ve iş tatmininin rolü: Çoklu aracılı bir model testi. H.Ü. İktisadi ve İdari Bilimler Fakültesi Dergisi, 32(2), 57 74. doi: 10.17065 /huiibf.88663

Brief, A.P. (1998). Attitudes in and around organizations. California: SAGE Publications.

Burmacıŏglu, S., Polat, M. ve Meydan, C.H. (2013). Örgütsel davranış alanında ilişkisel analiz yöntemleri ve Türkçe yazında aracılık modeli kullanımı üzerine bir araştırma. Anadolu Üniversitesi Sosyal Bilimler Dergisi, 13(1), 13-26. Erişim adresi: https://kutuphane.dogus.edu.tr/mvt/pdf.php

Büyükbeşe, T. ve Gökaslan, M. (2018). İşe gömülmüşlük, işe adanmışlık ve işten ayrılma niyeti ilişkisi: Bir alan çalışması. Mukaddime, 9(2), 135-154. doi: 10.19059/mukaddime.376745 
Chang, C. H., Rosen, C. C. ve Levy, P. E. (2009). The relationship between perceptions of organizational politics and employee attitudes, strain and behavior: A meta-analytic examination. Academy of Management Journal. 52(4), 779-801. doi: 10.5465/amj.2009.43670894

Chang, C., Rosen, C.C., Siemieniec, G. ve Johnson, R. (2012). Perceptions of organizational politics and employee citizenship behaviors: Conscientiousness and self-monitoring as moderators. Journal of Business \& Psychology, 27(4), 395-406. doi: 10.1007/s10869-012-9257-6

Chen, S.Y., Wang, J.Y., Chang, C.S., Weng, H.C. (2017). Relational model of organizational politics perception, job satisfaction, job stress, and organizational commitment in hospital nursing staff. Arch Nurs Pract Care, 3(1), 84-93. doi: 10.17352/2581-4265.000031

Chhetri, P., Afshan, N., ve Chatterjee, S. (2016). The impact of perceived organizational politics on work attitudes: The moderating role of leader-member-exchange quality. International Journal of Human Capital and Information Technology Professionals, IGI Global, 5(2), 1-13. Erişim adresi: https://ideas.repec.org/a/igg/jhcitp/v5y2014i2p1-13.html

Cho, H. ve Yang, J. (2018). How perceptions of organizational politics influence self-determined motivation: The mediating role of work mood. Asia Pasific Management Rewiev, 23, 60-69. doi: 10.1016/j.apmrv.2017.05.003

Cohen, A. (1998). An examination of the relationship between work commitment and work outcomes among hospital nurses. Scandinavian Journal of Management, 14(1/2),1-17. doi: 10.1016/S0956-5221(97)00033$\mathrm{X}$

Cote, S. ve Morgan, L.M. (2002). A longitudinal analysis of the association between emotion regulation, job satisfaction, and intentions to quit. Journal of Organizational Behavior, 23, 947-962. doi: 10.1002/job.174

Cotton, J.L. ve Tuttle, J.M. (1986). Employee turnover: A meta-analysis and review with implications for research. The Academy of Management Review, 11(1), 55-70. doi: 10.2307/258331

Crede, M., Chernyshenko, O.S., Stark, S., Dalal, R.S. ve Bashshur, M. (2007). Job satisfaction as mediator: An assesment of job satisfactions' position within the nomological network. Journal of Occupational and Organizational Psychology, 8(3), 515-538. doi: 10.1348/096317906X136180

Çankaya, S., Gürdal, O., Tunç, T. ve Orhan, H. (2018). Eğitim-Araştırma hastanelerinde çalışanların iş doyumu, örgütsel bağlllık ve tükenmişlik düzeyleri arasındaki ilişkilerin yapısal eşitlik modeli ile incelenmesi: Ordu ili örneği. SDÜ Tip Fakültesi Dergisi, 25(4), 436-449. doi: 10.17343/sdutfd.439841

Çavuşoğlu, S. ve Palamutçuoğlu, B.T. (2017). İş tatmininin sanal kaytarma üzerindeki etkisi. Mehmet Akif Ersoy Üniversitesi Sosyal Bilimler Enstitüsü Dergisi, 9, 430-444. doi: 10.20875/makusobed.289250

Çelik, M. ve Yıldız, B. (2018). Hemşirelerde mesleki bağllıı, özdeşleşme ve işten ayrılma niyeti ilişkisi: Kamu ve özel sektör karşılaştırması. Kastamonu Üniversitesi İktisadi ve İdari Bilimler Fakültesi Dergisi, 20(2), 47-75. Erişim adresi: https://dergipark.org.tr/tr/pub/iibfdkastamonu/issue/36745/343309

Çelik, S., Dedeoğlu, B.B. ve İnanır, A. (2015). Otel işletmelerindeki etik liderlik, örgütsel bağlllık ve iş tatmini arasındaki ilişki. Ege Akademik Bakış Dergisi, 15(1), 53-64. Erişim adresi: https://dergipark.org.tr/tr/pub/eab/issue/39935/474443

Çelikkalp, Ü., Temel, M. ve Bilgiç, Ş. (2019). Akademisyenlerin iş doyumu ve etkileyen faktörler. Yükseköğretim Dergisi, 9(1), 59-66. doi:10.2399/yod.18.031 
Çivici, T. (2016). İş doyumu, demotivasyon faktörleri ve tükenmişlik arasındaki ilişki: Mimarlar üzerine bir araştırma. Trakya Üniversitesi Sosyal Bilimler Dergisi, 18(2), 131-150. Erişim adresi: https://dergipark.org.tr/tr/pub/trakyasobed/issue/ 30207/326001

Dağdeviren, N., Musaoğlu, Z., Ömürlü, İ.K. ve Öztora, S. (2011). Akademisyenlerde iş doyumunu etkileyen faktörler. Balkan Med J, 28, 69-74. doi: 10.5174/tutfd.2010.04370.1

Davis, K. (1088), İşletmelerde insan davranışı örgütsel davranış, Çev. Kemal TOSUN ve diğerleri, İstanbul Üniversitesi İşletme Fakültesi Yayını, Yayın No 199.

Demirci, U. (2019a). İş doyumu ile işten ayrılma niyeti ilişkisine istihdam şekillerinin etkisi. Uluslararası Sosyal Araştırmalar Dergisi, 12(62), 1246-1258. Erişim adresi: https://www.sosyalarastirmalar.com

Demirci, U. (2019b). The effect of private security police cooperation on the relationship between job satisfaction and occupational commitment. Business \& Management Studies: An International Journal, 7(2), 969-997. doi: 10.15295/bmij.v7i2.1097

Demirci, U. ve Ergen, B. (2020). The effect of wage on the private security officers job satisfaction and intention to quit: An emprical study in Turkey. Elektronik Sosyal Bilimler Dergisi, 19(75), 1314-1334. https://doi.org/10.17755/esosder.616419

Demirci, U. ve Tekiner, M.A. (2019). Örgütsel sinizm ile işten ayrılma niyeti ilişkisi: Kamu ve özel sektör farkı. İşletme Araştırmaları Dergisi, 11(3), 2306-2321. doi: 10.20491/isarder.2019.741

Derik, D. (2019). Ulusal yazın bağlamında işten ayrılma niyetinin öncüllerine ilişkin bir meta-analiz çalışması. Yönetim ve Ekonomi, 26(1), 131-155. doi: 10.18657/yonveek.520699

Dığın, Ö. ve Ünsar, S. (2010). Çalışanların iş güvencesi algılarının belirleyicileri ve iş güvencesinden memnuniyetin organizasyonrl bağllık, iş stresi ve işten ayrılma niyetine etkisi. Dumlupınar Üniversitesi Sosyal Bilimler Dergisi, 26, 133-145. Erişim adresi: http://www.acarindex.com/dosyalar/makale/acarindex-1423876643.pdf

Egan, T.M., Yang, B. ve Bartlett, K.R. (2004). The effects of organizational learning culture and job satisfaction on motivation to transfer learning and turnover intention. Human Resource Development Quarterly, 15(3), 279-301. doi: 10.1002/ hrdq.1104

Emami, R., Moradi, E., Idrus, D. ve Almutairi, D.O. (2012). Investing the relationship between organizational learning culture, job satisfaction and turnover intention in it SMEs. International Journal of Innovative Ideas, 12(1), 8-23. Erişim adresi: http://www.publishtopublic.com

Engin, T. (2008). Sportif organizasyonlarda özel güvenlik. Türk İdare Dergisi, S: 460 (Eylül), 169-179. Erişim adresi: http://www.tid.gov.tr/Sayfalar/TumSayilar.aspx

Erbaşı, A. (2019). Performans değerlendirme hatalarının çalışanların işten ayrılma niyetleri ve yöneticilerine güvenleri üzerindeki etkisi. Uluslararası Yönetim İktisat ve İşletme Dergisi, 15(1), 223-240. doi: 10.17130/ijmeb.2019149867

Eryılmaz, İ. ve İspirli, D. (2014). Algılanan örgütsel politikanın iş tatminine etkisi: Örgüt ikliminin aracılık rolü. 2. Örgütsel Davranış Kongresinde sunulan bildiri. Kayseri. Erişim adresi: https://avesis.erciyes.edu.tr/yayin/0c7e4d65-ec9a-4e05-ac41-072d3fa135a7/2-orgutsel-davraniskongresi-bildiriler-kitabi

Eryılmaz, M. B. (2006). Özel güvenlik, Ü. Cizre (Ed.), Almanak Türkiye 2005 güvenlik sektörü ve demokratik gözetim (s.124-133) içinde, İstanbul: TESEV Yayınları. 
Ferris, G. R., Frink, D. D., Galang, M. C., Zhou, J., Kacmar, K. M., ve Howard, J. L. (1996). Perceptions of organizational politics: Prediction, stress-related implications, and outcomes. Human Relations, 49, 233266. doi: $10.1177 / 001872679604900206$

Ferris, G. R., Russ, G. S. ve Fandt, P. M. (1989). Politics in organizations. R. A. Giacalone \& P. Rosenfeld (Ed.), Impression management in the organization (s.143-170) içinde, Hillsdale, NJ: Lawrence Erlbaum Associates.

Ferris, G.R. ve Kacmar, K.M. (1992). Perception of Organizational Politics. Journal of Management. 18(1), 93116. doi: $10.1177 / 014920639201800107$

Ferris, G.R., Fedor, D.B., Chachere, J.G. ve Pondy, L.R. (1989). Myths and politics in organizational contexts. Group and Organization Studies, 14, 83-103. doi: 10.1177/105960118901400108

Ferris, G.R., Adams, G., Kolodinsky, R.W., Hochwarter, W.A. ve Ammeter, A.P. (2002). Perceptions of organizational politics: Theory and research directions. F.J. Yammarino ve F. Dansereau (Eds.), Research in multi-level issues (Cilt 1) içinde. Oxford: JAI Press/Elsevier Science. doi: 10.1016/S14759144(02)01037-8

Ferris, G.R., Frink, D.D., Bhawuk, D.P., Zhou, J. ve Gilmore, D.C. (1996). Reactions of diverse groups to politics in the workplace. Journal of Management, 22(1), 23-44. doi: 10.1177/014920639602200102

Frenkel, S., Sanders, K. ve Bednall, T. (2012). Employee perceptions of management relations as influences on job satisfaction and quit intentions. Asia Pacific Journal of Management, 30, 7-29. doi: 10.1007/s10490012-9290-z

Gandz, J. ve Murray, V. V. (1980). The experience of workplace politics. Academy of Management Journal. 23(2), 237-251. doi: 10.2307/255429

Gbadamosi, L. ve Chinaka, N.J. (2011). Organizational politics, turnover intention and organizational commitment as predictors of employees' efficiency and effectiveness in academia. Proceeding of Informing Science \& IT Education Conference konferansinda sunulan bildiri, Serbia and Montenegro. doi: $10.28945 / 1461$

Ghiselli, R., La Lopa, M. ve Bai, B. (2001). Job satisfaction, life satisfaction, and turnover intent: Among foodservice managers. The Cornell Hotel and Restaurant Administration Quarterly, 42(2), 28-37. doi: 10.1016/S0010-8804(01)80036-7

Griffeth, R.W., Hom, P.W. ve Gaertner, S. (2000). A meta-analysis of antecedents and correlates of employee turnover: Update, moderator tests and research implications for the next millennium. Journal of Management, 26, 463-88. doi: 10.1177/014920630002600305

Gull, S. ve Zaidi, A. A. (2012). Impact of Organizational politics on employees' job satisfaction in the health sector of Lahore Pakistan. Interdisciplinary Journal of Contemporary Research in Business, 4(2). 156-170. Erişim adresi: https://journal-archieves19.webs.com/156-170.pdf

Güzel, B. ve Ayazlar, G. (2014). Örgütsel adaletin örgütsel sinizm ve işten ayrılma niyetine etkisi: Otel işletmeleri araştırması. KMÜ Sosyal ve Ekonomik Araştırmalar Dergisi, 16(26), 133-142. Erişim adresi: https://hdl.handle.net/11492/560

Hançer, M. ve George, R. T. (2003). Job satisfaction of restaurant employees: An emprical investigation using the Minnesota Satisfaction Questionnaire. Journal of Hospitality \&Tourism Research, 27(1), 85-100. doi: $10.1177 / 1096348002238882$ 
Harris, K.J., James, M. ve Boonthanom, R. (2005). Perceptions of organizational politics and cooperation as moderators of the relationship between job strains and intent to turnover. Journal of Managerial Issues, 17(1), 26-42. Erişim adresi: https://www.jstor.org/stable/40604473

Harris, R.B., Harris, K.J. ve Harvey, P.A. (2007). A test of competing models of the relationships among perceptions of organizational politics, perceived organizational support, and individual outcomes. The Journal of Social Psychology, 147(6), 631-655. doi: 10.3200/SOCP.147.6.631-656

Hassan, H., Vina, T.M.H. ve Ithnin, N.S. (2017). Perceived organizational politics nd job satisfaction: The role of personality as moderator. Log Forum, 13(4), 479-493. doi: 10.17270/J.LOG.2017.4.8

Hom, P.W., Caranikas-Walker, F., Prussia, G.E. ve Griffeth, R.W. (1992). A meta analytical structural equations analysis of a model of employee turnover. Journal of Applied Psychology, 77(6), 890-909. doi: 10.1037/0021-9010.77.6.890

Huang, I.C., Chuang, C.H.J. ve Lin, H.C. (2003). The role of burnout in the relationship between perceptions off organizational politics and turnover intentions. Public Personnel Management, 32(4), 519-531. doi: $10.1177 / 009102600303200404$

İstanbul Güvenlik Anonim Şirketi. (2019, 9 Ekim). Erişim adresi: https://istguven.istanbul/ozel-guvenliksektoru-buyuyor/.

Javed, A., Gulzar, A. ve Hussain, W. (2015). Organizational politics and bank frontline employee outcomes with the mediating role of work engagement. International Journal of Academic Research in Business and Social Sciences, 5(3), 225-233. doi: 10.6007/IJARBSS/v5-i3/1519

Kacmar, K. M. ve Ferris, G. R. (1991). Perceptions of Organizational Politics Scale (POPS): Development and construct validation. Educational and Psychological Measurement, 51, 193-205. doi: $10.1177 / 0013164491511019$

Kacmar, K.M. ve Baron, R.A. (1999). Organizational politics: The state of the field links to related processes, and an agenda for future research. K.M. Rowland, G.R. Ferris (Ed.), Research in Personnel and Human Resources Management (s.1-39) içinde, JAI Press Inc., Greenwich.

Kacmar, K.M. ve Carlson, D.S. (1997). Further validation of the Perceptions of Politics Scale (POPS): A multiple sample investigation. Journal of Management, 23(5), 627-658. doi: 10.1016/S01492063(97)90019-2

Karacaoğlu, K. (2015). Çalışanların iş güvencesizliğinin işten ayrılma niyetleri üzerindeki etkisi: Alanya bölgesindeki beş yıldızlı otellerde bir araştırma. Uluslararası Alanya İşletme Fakültesi Dergisi, 7(1), 1321. Erişim adresi: https://kutuphane.dogus.edu.tr/mvt/pdf.php

Karatepe, O.M. (2011). Perceptions of organizational politics and hotel employee outcomes: The mediating role of work engagement. IJCHM, 25(1), 82-104. doi: 10.1108/09596111311290237

Kasalak, G. (2019). Algılanan örgütsel toksisitenin iş doyumu üzerine etkisi: Duygusal bağlılığın aracı rolü. International Journal of Society Research, 13(19), 1283-1309. doi: 10.26466/opus.537424

Kaymaz, K. ve Erbi, H. (2018). Bilgi güvenliğinde stres faktörlerinin iş tatmini üzerindeki etkileri: AR-GE merkezi olan işletmeler üzerinde bir araştırma. İSGUC The Journal of Industrial Relations and Human Resources, 20(4), 95-112. Erişim adresi: http://hdl.handle.net/11452/1138

Khalid, S. ve Ishaq, S. (2015). Job related outcomes in relation to perceived organizational politics. Pakistan Economic and Social Review, 53(1), 133-148. Erişim adresi: http://pu.edu.pk/images/journal/pesr/PDFFILES/7\%20KHALID\%20Job\%20Related_v53_1_15.pdf 
Khan, A. ve Hussain, N. (2016). The analysis of the Perception of Organizational Politics among university faculty. Pakistan Business Review. 18(2), 451-467. Erişim adresi: https://journals.iobmresearch.com/index.php/PBR/article/view/826/163

Köroğlu, Ö. (2012). İçsel ve dışsal iş doyum düzeyleri ile genel iş doyum düzeyi arasındaki ilişkinin belirlenmesi: Turist rehberleri üzerinde bir araştırma. Doğuş Üniversitesi Dergisi, 13(2), 275-289. Erişim adresi: http://journal.dogus.edu.tr/index.php/duj/ article/view/576

Kumar, P. ve Ghadially, R. (1989). Organizational politics and its effects on members of organizations. Human Relations, 42(2), 305-314. doi: 10.1177/ 001872678904200402

Kurnaz, S. (2019). Liderlik tarzı örgütsel sessizlik ilişkisinde örgütsel politikanın düzenleyici rolü: Kamu kurumlarında bir araştırma. (Yayınlanmamış doktora tezi). İnönü Üniversitesi Sosyal Bilimler Enstitüsü Siyaset Bilimi ve Kamu Yönetimi Anabilim Dalı.

Kurt, H. S. (2019). Psikolojik sözleşme ihlalinin işten ayrılma niyeti üzerindeki etkisinde çalışanın algıladığı lider-üye etkileşimi kalitesinin rolü. (Yayınlanmamış doktora tezi). İstanbul Arel Üniversitesi Sosyal Bilimler Enstitüsü.

Kurt, İ. (2010). Rol stres kaynakları ve iş tatmini arasındaki ilişkide amirin algılanan sosyal desteğinin etkisi. Organizasyon ve Yönetim Bilimleri Dergisi, 2(1), 79-87. Erişim adresi: https://dergipark.org.tr/tr/pub/oybd/issue/16335/171012

Labrague, L.J., McEnroe-Petitte, D.M., Gloe, D., Tsaras, K., Arteche, D.L. ve Maldia, F. (2017). Organizational politics, nurses' stress, burout levels, turnover intention and job satisfaction. International Nursing Review, 64 (1), 109-116. DOI: 10.1111/inr.12347

Lambert, E. G., Lynne Hogan, N. ve Barton, S. M. (2001). The impact of job satisfaction on turnover intent: A test of a structural measurement model using a national sample of workers. The Social Science Journal, 38(2), 233-250. doi: 10.1016/S0362-3319(01)00110-0

Locke, A.E. (1983). The Nature and cause of job satisfaction. M.Dunnette (Ed.), Handbook of Industrial and Organizational Psychology (s.1297-1349) içinde. New York: John Wiley and Sons.

Maden Turgut, E. (2010). İş doyumu ve yaşam doyumu ilişkisi ve İstanbuldaki devlet üniversite hastanelerinde çalışan ameliyathane hemşirelerine yönelik bir araştırma. (Yayınlanmamış yüksek lisans tezi). İstanbul Üniversitesi Sosyal Bilimler Enstitüsü.

Masum, A.K., Azad, M.A., Hoque, K.E., Beh, L.S., Wanke, P. ve Arslan, Ö. (2016). Job satisfaction and intention to quit: An emprical analysis of nurses in Turkey. PeerJ, 26(4), doi: 10.7717/peerj.1896

Mayes, B. T. ve Allen, R. W. (1977). Toward a definition of organizational politics. The Academy of Management Review, 2(4), 672-678. doi: 10.5465/amr.1977. 4406753

Meisler, G. ve Vigoda-Gadot, E. (2014). Perceived organizational politics, emotional intelligence and work outcomes: Empirical exploration of direct and indirect effects. Personnel Review, 43(1), 116-135. doi: 10.1108/PR-02-2012-0040

Miller, B.K., Rutherford, M.A. ve Kolodinsky, R.W. (2008). Perceptions of organizational politics: A metaanalysis of outcomes. Journal of Business and Psychology, 22(3), 209-222. doi: 10.1007/s10869-008-90615

Mintzberg, H. (1983). Power in and around organizations. Englewood Cliffs, NJ: Prentice-Hall.

Mintzberg, H. (1985). The organization as political arena. Journal of Management Studies, 22(2), 133-154. doi: 10.1111/j.1467-6486.1985.tb00069.x

Mobley, W.H. (1982). Employee turnover: Causes, consequences, and control. Massachusetts: Addison-Wesley Series on Managing Human Resources. 
Mobley,W. H., Griffeth, R., Hand, H. ve Meglino, B. (1979). A review and conceptual analysis of the employee turnover process. Psychological Bulletin, 86, 493-522. doi: 10.1037/0033-2909.86.3.493

Mohan Bursalı, Y. ve Bağcı, Z. (2011). Çalışanların örgütsel politika algıları ile politik davranışları arasındaki karşılıklı ilişkiler. Pamukkale Üniversitesi Sosyal Bilimler Enstitüsü Dergisi, 9, 23-41. Erişim adresi: https://dergipark.org.tr/tr/pub/pausbed/ issue/34721/383879

Mosadeghrad, A. M., Ferlie, E. ve Rosenberg, D. (2011). A study of relationship between job stress, quality of working life and turnover intention among hospital employees. Health Services Management Research, 24, 170-181. doi:10.1258/hsmr.2011.011009

Muchinsky, P.M. (2000). Psychology applied to work (Sixth Edition). USA: Wadsworth

Muhammad, A. H. (2007). Antecedents of organizational politics perceptions in Kuwait business organizations. Competitiveness Review: An International Business Journal, 17(4), 234-247. doi:10.1108/10595420710844325

Naktiyok, S. ve Yıldırım, F. (2018). Etik iklimin iş tatmini ve işe yabancılaşma düzeyine etkisi, ETÜ Sosyal Bilimler Enstitüsü Dergisi, 3(6), 57-71. Erişim adresi: https://dergipark.org.tr/tr/pub/etusbed/issue/40179/477946

O’Neill, J. W., Harrison, M. M., Cleveland, J., Almeida, D., Stawski, R. ve Crouter, A.C. (2009). Work-Family climate, organizational commitment, and turnover: Multilevel contagion effects of leaders. Journal of Vocational Behavior, 74(1), 18-29. doi: 10.1016/j.jvb.2008.10.004

Ocak, M., Güler, M. ve Basım, H.N. (2016). Psikolojik sermayenin örgütsel bağlllık ve iş tatmini tutumları üzerine etkisi: Bosnalı öğretmenler üzerine bir araştırma. Çankırı Karatekin Üniversitesi İİB Dergisi, 6(1), 113-130. doi: 10.18074/cnuiibf.274

Ojiabo, N.T.J.U. ve Alagah, A.D. (2017). Organizational politics and employee's job satisfaction in the health sector of Rivers State. International Journal of Advanced Academic Research, 3 (7), 88-106. Erişim adresi: https://www.ijaar.org/articles/Volume3-Number7/Social-Management-ciences/ijaar-sms-v3n6-jn17p17.pdf

Orhaner, E. ve Mutlu, S. (2019). Sağlık personelinin iş tatmininin motivasyon üzerine etkisi. Uluslararası Sağlık Yönetimi ve Stratejileri Dergisi, 4(1), 74-93. Erişim adresi: https://dergipark.org.tr/tr/download/articlefile/471497

Ölçer, F. (2015). The investigation of the relationship between organizational justice and turnover intention: The mediating role of organizational commitment. Economic Computation \& Economic Cybernetics Studies \& Research, 49(3), 223-241. Erişim adresi: http://www.ecocyb.ase.ro/nr20153/14\%20\%20Ferit\%20Olcer.pdf

Özdemir, F. (2006). Örgütsel iklimin iş tatmin düzeyine etkisi: Tekstil sektöründe bir araştırma. (Yayınlanmamış doktora tezi). Çukurova Üniversitesi Sosyal Bilimler Enstitüsü İşletme Anabilim Dalı.

Özkalp, E. ve Kırel, Ç. (2013). Örgütsel davranış. Bursa: Ekin Yayınevi.

Öztürk Çiftçi, D., Meriç, E. ve Meriç, A. (2015). Örgütsel sessizlik, tükenmişlik ve işten ayrılma niyeti ilişkisi: ordu ili özel eğitim ve rehabilitasyon merkezlerinde bir uygulama. Uluslararası Sosyal Araştırmalar Dergisi, $\quad$ 8(41), 996-1007. Erişim adresi: https://www.sosyalarastirmalar.com/cilt8/sayi41_pdf/5egitim/ozturkciftci_didem_erdalmeric.pdf

Paille, P. (2006). The relationship between job involvement, organizational citizenship and intention to withdrawal. European Review of Applied Psychology, 56(2), 139-149. doi: 10.1016/j.erap.2005.06.001

Park, J., Yoon, S., Moon, S.S., Lee, K.H. ve Park, J. (2017). The effect of occupational stress, work-centrality, self-efficacy, and job satisfaction on intent to quit among long-term care workers in Korea. Home Health Care Services Quarterly, 36(2), 96-111. doi: 10.1080/01621424.2017.1333479 
Parker, C.P., Dipboye, R.I. ve Jacson, S.I. (1995). Perceptionas of organizational politics: An investigation of antecedents and consequences. Journal of Management, 21(5), 891-912. doi: $10.1177 / 014920639502100505$

Pekmezci, M., Ateş, M.F. ve Turgut, H. (2017). The moderating role of job satisfaction on the relationship between servant leadership and turnover intention. İsletme Araştırmaları Dergisi, 9(2), 300-314. Erişim adresi: https://isarder.com/2017/vol.9_issue.2_article16_extensive_summary.pdf

Pfeffer, J.(1981). Power in organizations (Vol. 33). Marshfield, MA: Pitman.

Poon, J. (2004). Effects of performance appraisal politics on job satisfaction and turnover intention. Personnel Review, 33(3), 322-334. doi: 10.1108/00483480410528850

Poon, J. M. (2003). Situational antecedents and outcomes of organizational politics perceptions. Journal of Managerial Psychology, 18(2), 138-155. doi: 10.1108/026839403104 65036

Porter, L.W., Steers, R.M., Mowday R.T. ve Boulian, P.V. (1974). Organizational commitment, job satisfaction and turnover among psychiatric technicians. Journal of Applied Psychology, 59(5), 603-609. doi: $10.1037 / \mathrm{h} 0037335$

Price, J. L. (2001). Reflections on the determinants of voluntary turnover. International Journal of Manpower, 22(7), 660-624. doi: 10.1108/EUM0000000006233

Price, J.L. ve Mueller, C.W. (1986) Absenteeism and turnover among hospital employees. Greewich, CT:JAI Pres

Rahman, U., Sulaiman, W.S.W., Nasir, R. ve Omar, F. (2014). The role of job satisfaction as mediator in the relationship between self-efficacy and organizational citizenship behavior among Indonesian teachers. International Journal of Business and Social Science, 5(9), 255-261. Erişim adresi: http://www.ijbssnet.com/journals/Vol_5_No_9_August_2014/30.pdf

Ridaryanto, P., Ghozali, I. ve Purwanto, A. (2017). Job satisfaction as a moderating variable in the relationship between organizational justice and acceptance of dysfunctional audit behaviour. International Business Management, 11(11), 1953-1963. doi: 10.36478/ibm.2017.1953.1963

Rizwan, M., Shahid, M., Shafiq, H., Tabassum, S., Bari, R. ve Umer, J. (2013). Impact of psychological factors on employee turnover intentions, International Journal of Research in Commerce, Economics and Management, 3(3), 63-69. doi:10.5296/ ijhrs.v4i2.5906

Scott C. R., Connaughton S. L., Diaz-Saenz H. R., Maguire K., Ramirez R., Richardson B., Shaw S. P. ve Morgan D. (1999). The impacts of communication and multiple identifications on intent to leave: A multimethodological exploration. Management Communication Quarterly. 12, 400-435. Erişim adresi: http://comminfo.rutgers.edu/images/comprofiler/plug_profilegallery/98/pg_936611571.pdf

Semercioğlu, S., Tengilimoğlu, D. ve Semercioğlu, M.G. (2012). Özel ve kamu hastanelerinde çalışan tıbbi sekreterlerin iş doyumu ve örgütsel güven düzeylerinin karşılaştırılmasına yönelik bir alan araştırması. Gümüşhane Üniversitesi Sağllk Bilimleri Dergisi, 1(4), 225-238. Erişim adresi: https://dergipark.org.tr/tr/pub/gumussagbil/issue/7506/98947

Serçeoğlu, N., Işık, Z. ve Çetinkaya, M.Y. (2016). İşyeri zorbalığının işten ayrılma niyeti üzerine etkisi: Konaklama işletmelerinde çalışan personel üzerine bir araştırma. Uluslararası Sosyal Araştırmalar Dergisi, 9(45), 1099-1109. doi: 10.17719/jisr.20164520683

Sevimli, F. ve İşcan, Ö.F. (2005). Bireysel ve iş ortamına ait etkenler açısından iş doyumu. Ege Üniversitesi, I.I.̇.F. Akademik Bakış Dergisi, 5(1-2), 55-64. Erişim adresi: https://dergipark.org.tr/en/pub/eab/issue/39836/472327

Shore, L. M., Newton, L. A. ve Thornton, G. C. (1990). Job and organizational attitudes in relation to employee behavioral intentions. Journal of Organizational Behavior, 11(1), 57-67. doi: 10.1002/job.4030110108 
Sidin, J.P., Stephen, L.S.Jr. ve Jennifer, B. (2015). Family-Work conflict and intention to quit among hotel employees in Sabah. Malaysian Journal of Business and Economics, 2(1), 63-81. Erişim adresi: https://www.ums.edu.my/mjbe/images/mjbe/2015/ vol2/5.pdf

Summers, T.P. ve Hendrix, W. H. (1991). Modeling the role of pay equity perceptions: A field study. Journal of Occupational Psychology, 64(1), 145-157. doi: 10.1111/j.2044-8325.1991.tb00549.x

Şevik, Ü. (2019). Algılanan örgütsel politika ile pozitif psikolojik sermayenin iş tatmini, işten ayrılma niyeti ve örgütsel sessizlik üzerine etkisi (Yayınlanmamış doktora tezi). Sakarya Üniversitesi, İşletme Enstitüsü.

Tan, Ç. ve Ulaş, A.H. (2016). İlköğretim okul yöneticilerinin takım liderlik davranışlarının öğretmenlerin iş doyumu, örgütsel adanmışlık ve örgütsel vatandaşlık düzeylerine etkisi. EKEV Akademi Dergisi, 20 (65), 65-80. Erişim adresi: http://www.ekevakademi.org/Makaleler/1369054179_04\%20Cetin\%20TAN.pdf

Tanova, C. ve Holtom, B. C. (2008). Using job embeddedness factors to explain voluntary turnover in four European countries. The International Journal of Human Resource Management, 19(9), 1553-1568. doi: $10.1080 / 09585190802294820$.

Taslak, S. (2015). Banka çalışanlarının işten ayrılma niyetleri üzerinde etkili olan faktörlere yönelik bir araştırma: Muğla ili örneği. Mehmet Akif Ersoy Üniversitesi Sosyal Bilimler Enstitüsü Dergisi, 7(12), 145160. Erişim adresi: https://dergipark.org.tr/tr/pub/makusobed/issue/19444/206861

Taşlıyan, M. ve Hırlak B. (2016). Otantik liderlik, psikolojik sermaye, işten ayrılma niyeti ve çalışan performansı arasındaki ılişki: Hemşireler üzerinde bir araştırma. Akademik Bakış Uluslararası Hakemli Sosyal Bilimler Dergisi, 56, 92-115. Erişim adresi: https://www.akademikbakis.org/

Terason, Z. (2018). Managerial turnover intention as a result of leadership behavior, job satisfaction and organizational commitment: Evidence from cross-national fitness enterprises in Thailand. Academy of Strategic Management Journal, 17(1), 1-12. Erişim adresi: https://www.abacademies.org/journals/academy-of-strategic-management-journal-home.html

Tett, R. P., ve Meyer, J. P. (1993). Job satisfaction, organizational commitment, turnover intention, and turnover: Pathanalyses based on meta-analytic findings. Personnel Psychology, 46, 259-293. doi: 10.1111/j.1744-6570.1993.tb00874.x

Thau, S. ve Mitchell, M. S. (2010). Self-gain or self-regulation impairment? Tests of competing explanations of the supervisor abuse and employee deviance relationship through perceptions of distributive justice. Journal of Applied Psychology, 95(6), 1009-1031. doi:10.1037/a0020540

Tolay-Sabuncuoğlu, E. (2007). Eğitim, örgütsel bağlllık ve işten ayrılma niyeti arasındaki ilişkilerin incelenmesi. Ege Akademik Bakış, 7(2), 631-636. doi: 10.18657/yonveek.520699

Töngel, E. (2015). Örgütsel bağlılık ve amaç karşıtı iş davranışları arasındaki ilişkide iş doyumunun rolü. (Yayınlanmamış yüksek lisans tezi). Abant İzzet Baysal Üniversitesi Sosyal Bilimler Enstitüsü.

Tuncer, M. (2014). Otel çalışanlarının işten ayrılma eğilimi: Sayfiye ve şehir otellerinde bir uygulama. Atatürk Üniversitesi Sosyal Bilimler Enstitüsü Dergisi, 18(3), 419-430. Erişim adresi: https://dergipark.org.tr/tr/pub/ataunisosbil/issue/2837/38718

Türkiye Odalar ve Borsalar Birliği. (2014). Türkiye özel güvenlik hizmetleri meclisi sektör raporu 2014. Ankara. Erişim adresi: https://tobb.org.tr/Documents/yayinlar/2014/ozel_guvenlik_meclisi_int.pdf.

Uslu, S. ve Aktaş, H. (2017). İşten ayrılma niyeti ile örgütsel sessizlik etkileşiminde iş güvencesi memnuniyeti ve iş güvencesi endeksinin aracı rolü: Özel bir hastane çalışanları üzerinde bir araştırma. Eskişehir Osmangazi Üniversitesi İktisadi ve İdari Bilimler Dergisi, 12, 141-160. doi: 10.17153/oguiibf.298772 
Uysal-Irak, D. (2014). Birey-Çevre uyumu: Çalışanların örgüt uyumlarının yaşama ilişkin doyum ve işten ayrılma niyetiyle ilişkisi. Türk Psikoloji Dergisi, 29(74). 34-45. Erişim adresi: https://www.psikolog.org.tr/tr/yayinlar/dergiler/1031828/tpd130044332014 0000m000047.pdf

Valle, M. ve Perrewe, P. L. (2000). Do politics perceptions relate to political behaviors? Tests of an implicit assumption and expanded model. Human Relations, 53(3), 359-386. doi: 10.1177/0018726700533004

Valle, M. ve Witt, L.A. (2001). The moderating effect of teamwork perceptions on the organizational politicsjob satisfaction relationship. The Journal of Social Psychology, 141(3), 379-388. doi: 10.1080/00224540109600559

Van Schalkwyk, S., Du Toit, D.H., Bothma, A.S. ve Rothmann, S. (2010). Job insecurity, leadership empowerment behaviour, employee engagement and intention to leave in a petrochemical laboratory: original research. SA Journal of Human Resource Management, 8(1), 1-7. doi: 10.4102/ sajhrm.v8i1.234

Vieira, J.A.C. (2005). Skill mismatches and job satisfaction. Economic Letters, 89, 39-47. Erişim adresi: http://www.sciencedirect.com/science/article/pii/S0165-1765(05)00183-7

Vigoda, E. (2001). Reactions to organizational politics: A cross-cultural examination in Israel and Britain. Human Relations, 54(11), 1483-1518. doi: 10.1177/00187267015411004

Vigoda, E. ve Drory, A. (2006). Handbook of organizational politics. UK: Edward Elgar Publishing.

Wang, J. (2018). Relational model of organizational politics perception, job satsfaction, job stress, and organizational commitment in hospital nursing staff. Archives of Nursing Practice and Care, 3(1), 84-93. doi: 10.17352/ANPC.000031

Wang, Y., Yang, C. ve Wang, K. (2012). Comparing public and private employees' job satisfaction and turover. Public Prsonnel Management, 41(3), 557-573. doi: 10.1177/009102601204100310

Weiss, D.J., Dawis, R.W., England, G.W. ve Lofquist, L.H. (1967). Manual for the Minnesota Satisfaction Quesitionnaire. Erişim adresi: http://vpr.psych.umn.edu/sites/g/files/ pua2236/f/monograph_xxii__manual_for_the_mn_satisfaction_questionnaire.pdf.

Weng, Q., Wy, S., McElroy, J.C. ve Chen, L. (2018). Place attachment, intent to relocate and intent to quit: The moderating role of occupational commitment. Journal of Vocational Behavior, 108, 78-91. doi:10.1016/j.jvb.2018.06.002.308

Witt, L. A., Andrews, M. C. ve Kacmar, K. M. (2000). The role of participation in decision-making in the organizational politicsjob satisfaction relationship. Human Relations, 53(3), 341-358. doi: $10.1177 / 0018726700533003$

Yasım, Y.K. ve Uğur, A. (2016). Bankacı kadınların örgütsel sinizm algılarının işten yrılma niyetine etkisi: Ordu ili örneği. ODÜ Sosyal Bilimler Araştırmaları Dergisi, 15, 554-572. Erişim adresi: https://dergipark.org.tr/tr/pub/odusobiad/issue/27575/290223

Yavuz, M. ve Akça, M. (2018). Çatışma, stres, tükenmişlik ve işten ayrılma niyeti: Medeni durum ve cinsiyete göre farklılıkların incelenmesi. İşletme Araştırmaları Dergisi, 2, 827-846. doi: 10.20491/isarder.2018.457

Yazıcıoğlu, Y. ve Erdoğan, S. (2004). Spss uygulamalı bilimsel araştırma yöntemleri. Ankara: Detay Yayıncılık

Yeşilyurt, H. ve Koçak, N. (2013). İş doyumu ve örgütsel vatandaşlık davranışı arasındaki ilişkinin otel işletmeleri açısından incelenmesi. Dokuz Eylül Üniversitesi Sosyal Bilimler Enstitüsü Dergisi, 16 (2), 303324. doi: $10.16953 /$ deusbed.76900

Yıldırım, B. I. ve Yirik, Ş. (2014). İşgörenlerin iş güvencesi algıları ve işten ayrılma niyetleri ilişkisi: Belek bölgesi beş yıldızlı otel çalışanları örneği. Iğdır Üniversitesi Sosyal Bilimler Dergisi, 6, 123-140. Erişim adresi: http://sosbilder.igdir.edu.tr 
Yıldırım, F. (2007). İş doyumu ve örgütsel adalet ilişkisi. Ankara Üniversitesi SBF Dergisi, 62(1), 253-278. doi: 10.1501/SBFder_0000002016

Yıldız, Z., Ayhan, S. ve Erdoğmuş, Ş. (2009). The impact of nurses' motivation to work, job satisfaction, and sociodemographic characteristics on intention to quit their current job: An empirical study in Turkey. Applied Nursing Research, 22, 113-118. doi: 10.1016/j.apnr.2007.06.002

Yılmaz, B. (2016). Personel memnuniyetinin iş verimliliği üzerine etkisi: Gümrüksüz satış mağazasında bir uygulama. (Yayınlanmamış yüksek lisans tezi). İstanbul Gelişim Üniversitesi Sosyal Bilimler Enstitüsü. Erişim adresi: https://hdl.handle.net/ 11363/210

Yılmaz, B. ve Halıcı, A. (2010). İşgücü devir hızını etkileyen etmenler: Sekreterlik mesleğinde bir araştırma. Uluslararası İktisadi ve İdari İncelemeler Dergisi, 2(2), 94-95. Erişim adresi: https://dergipark.org.tr/tr/pub/ulikidince/issue/21623/232262

Yousef, D.A. (2002). Job satisfaction as a mediator of the relatonship between role stressors and organizational commitment: A studyfrom an Arabic cultural perspective. Journal of Managerial Psychology, 17(4), 250266. doi: $10.1108 / 02683940210428074$

Yusof, J.M., Zulkiffli, S.N.A., Padlee, S.F. ve Yusof, N.A. (2018). The relationship between organizational politics, job satisfaction and turnover intention in the maritime-related agencies in the east coast of Peninsular Malaysia. International Conference on Economics, Business and Education toplantisinda sunulan bildiri. doi: 10.18502/kss.v3i10.3188

Yücel, İ. ve Demirel, Y. (2013). Mevcut iş alternatiflerinin iş tatmini ve işten ayrılma ilişkisi üzerine etkisi: “Başka bir yol daha olmalı!”. Atatürk Üniversitesi İktisadi ve İdari Bilimler Dergisi, 27(2), 159-177. Erişim adresi: https:// dergipark.org.tr/tr/pub/atauniiibd/issue/2709/35850

Yüksel, H. ve Yüksel, M. (2014). İş doyumu ile işten ayrılma düzeyi arasındaki ilişki: İlköğretim öğretmenleri üzerinde bir uygulama. Uluslararası Sosyal Araştırmalar Dergisi, 7(32), 559-572. Erişim adresi: https://www.sosyalarastirmalar.com

Yüksel, M. (2013). Örgütsel politika, Hofstede’in örgüt kültürü boyutları, iş tutumları ve iş çıktıları ilişkisi (Yayınlanmamış doktora tezi). Balıkesir Üniversitesi Sosyal Bilimler Enstitüsü.

Zaleznik, A. (1999). Power and politics in organizational life. The McKinsey Quarterly, 7(4), 57-85. Erişim adresi: https://www.mckinsey.com/quarterly/overview\#

Zeynel, E. ve Çarıkçı, İ.H. (2015). Mesleki motivasyonun, iş tatmini ve örgütsel bağllıı üzerindeki etkisi: Akademisyenler üzerine görgül bir araştırma. SDÜ İktisadi ve İdari Bilimler Fakültesi Dergisi, 20(3), 217248. Erişim adresi: https://dergipark.org.tr/en/pub/sduiibfd/issue/20858/223750

Zeytinoglu, I. U., Denton, M., Davies, S., Baumann, A., Blythe, J. ve Boos, L. (2007). Deteriorated external work environment, heavy workload and nurses' job satisfaction and turnover intention. Canadian Public Policy, 33(1), 31-47. doi: 10.3138/0560-6GV2-G326-76PT

Zhang, T. (2018). The relationship of percieved organizational support to affective commitment, emotional exhaustion and turnover intention-A study of general practitioners in Shanghai Community Health Centers in China (Yayınlanmamış doktora tezi). ISCTE University Institute of Lisbon. Erişim adresi: http://hdl.handle.net/10071/17103 